\title{
GÖZALTINDA ALINAN İFADENİN ÖNEMİ VE DELIL DEĞERİ
}

The Importance and Evidence Value of The Statement In the Custody

\section{Dr. Pervin AKSOY İPEKÇIOĞLU*}

Giriş, I- Soruşturma Evresinde İfadenin Önemi ve Delil Değeri, ASoruşturma Evresinde Delil Kavramı, B-Soruşturma Evresinde İfadenin Önemi, 1- İfadenin Diğer Delil Araçlarına Ulaşmadaki Önemi, a- İfadenin İsnadın Konusunu Oluşturan Suçla İlgili Bir Delil Aracına Ulaşmadaki Önemi, b- İfadenin İsnadın Konusunu Oluşturan Suç Dışında Başka Bir Suç Teşkil Eden Fiile İlişkin Delil Araçlarına Ulaşmadaki Önemi, 2- İfadenin Kamu Davasının Açılmasındaki Önemi, II- Kovuşturma Evresinde İfadenin Delil Değeri, A- Genel Olarak, B- Cumhuriyet Savcısı Tarafından Alınan İfadenin Değeri, C- Kolluk Tarafından Alınan İfadenin Değeri, 1- Müdafi Olmaksızın Kolluk Tarafından Alınan İfadenin Değeri, 2- Müdafi Huzurunda Kolluk Tarafından Alınan İfadenin Değeri, D- İfade Tutanağının Hukukî Niteliği, Değerlendirme

\section{ÖZET}

Gözaltı, yakalanan kişinin Cumhuriyet savcısının kararı ile girdiği hukuki durumu ifade etmektedir. Gözaltında, klasik işlemler arasında şüpheli kişinin ifadesi de yer almaktadır. İfade, hem bir savunma aracı, hem de bir delil aracıdır. Bu nedenle, gözaltında alınan ifade soruşturma evresinde olduğu kadar, kovuşturma evresinde de delil değerine sahiptir. Soruşturma

\footnotetext{
* Doğu Akdeniz Üniversitesi Hukuk Fakültesi Ceza ve Ceza Usul Hukuku Ana Bilim Dalı Öğretim Görevlisi.
} 
evresinde alınan ifade, bir delil aracı olduğundan, gerek Cumhuriyet savcısının kamu davasını açmak için yeterli şüphe elde etmesinde, gerekse diğer delil araçlarına ulaşmada tartışılmaz bir öneme sahiptir.

5271 sayılı CMK., gözaltında alınan bu ifadeye, kovuşturma evresinde de değer tanımıştır. Nitekim CMK. 213. maddesinde, sanığın önceki ifadeleriyle duruşmadaki beyanı arasında çelişki bulunması ve bu ifadelerin hakim, mahkeme veya Cumhuriyet savcisı ya da müdafi huzurunda kolluk tarafından tutulan ifadeler olması halinde, duruşmada okunabileceği hükmü getirilmiştir. CMK. md. 213 ile birlikte değerlendirilecek olan diğer bir hüküm ise, md. 148/4 hükmüdür. Bu hükme göre, müdafi bulunmaksızın kollukta alınan ifadeler, doğrudan kovuşturma evresinde bir delil aracı olarak okunamaz ve dolayısıyla hükme esas alınamaz. Bu ifadelerin, mutlaka hakim veya mahkeme önünde şüpheli veya sanık tarafından tekrarlanması gerekmektedir. $\mathrm{O}$ halde, kollukta müdafii bulunmaksızın alınan ifadeler, hakim veya mahkeme huzurunda tekrarlanmaları koşuluyla kovuşturma evresine taşınabilir. şüphe

Anahtar Kelimeler: Gözaltı, ifade, hukuka aykırı delil, delil değeri,

\section{ABSTRACT}

Custody is a legal position that starts with the decision of the General Attorney. During custody, General Attorney or the police or the gendarmerie record the person's expression. Statement is a kind of evidence tool and a way of defence. Because of this, the statement in the custody has a value of evidence for either prior investigation or last investigation. In the prior investigation, it has an importance of both obtaining the other evidence tools and getting rid of the doubt by the General Attorney.

Code of Criminal Procedure which is the numbered of 5271 recognizes the value of evidence in the last investigation for the statement which is taken in the prior investigation by the General Attorney or the police or the gendarmerie. According to CCP. art. 213, if there is a conflict between the first and last statements and if the statements are recorded by the judge, the court or the General Attorney or the police or the gendarmerie in the presence of the advocates, the statements are read in the last investigation and also are used in the verdict. In the old code, the statements that were obtained by the General Attorney or the police or the gendarmerie were not included in the last investigation. When judge tried to reach the verdict, he could not use those statements as evidence tools (old art. 247/1). If there was a conflict between the first and last statements according to the old art. $247 / 2$, the first statement could be read in the last investigation for 
destroying the conflict between them. In spite of this, judge could not use those statements directly when he tried to reach the verdict. doubt

Keywords: Custody, satement, unlawful evidence, evidence value,

\section{Giriş}

İfade kavramı; yalnızca suç şüphesi altında olan kişinin savcı ve kolluk önünde yaptığı açıklamalar için değil, mağdurun, şikâyetçinin ya da ihbar edenin veya olaya tanık olan kişinin açıklamaları için de kullanılmaktadır. Ancak, biz, konumuz itibariyle, ifadeyi, suç şüphesi altında olan kişilerin savcılık veya kolluk önünde yaptığı açıklamalar ile sınırlı tutarak ele almaktayız. Bu nedenle, bu çalışmada "ifade”, suç şüphesi altında olan kişinin savcılıktaki veya kolluktaki açıklamaları anlamında kullanılacaktır. Zira, CMK. md. 2/1 (g) bendinde "ifade alma, şüphelinin kolluk görevlileri veya Cumhuriyet savcısı tarafindan soruşturma konusu suçla ilgili olarak dinlenmesi" biçiminde tanımlanmıştır.

1412 sayılı CMUK.'un 247. maddesinin 1. fikrası gereği, sanığın soruşturma aşamasında sulh ceza hâkimi huzurunda vermiş olduğu beyanının, duruşma sırasındaki ikrarına delil olmak üzere okunabileceği düzenlenmekteydi. Ayrıca, aynı maddenin 2. fıkrasında, sanığın Cumhuriyet savcısı veya kolluk tarafından alınan ifadeleriyle duruşma sırasındaki beyanı arasında bir çelişki olması ve bu çelişkiyi duruşmayı kesmeksizin ortadan kaldırma imkânının bulunmaması halinde, bunların duruşmada okunabileceği, ancak hüküm kurarken bu ifadelere dayanılamayacağı, esasen ifadeler okunduktan sonra sanığın duruşmada söylediklerinin delil olarak değerlendirilebileceği yer almaktaydı.

5271 sayılı CMK.'nın 213. maddesinde ise, sanığın önceki ifadeleriyle duruşmadaki beyanı arasında çelişki bulunması ve bu ifadelerin hâkim, mahkeme veya Cumhuriyet savcisı ya da müdafi huzurunda kolluk tarafından tutulan ifadeler olması halinde, duruşmada okunabileceği hükmü getirilmiştir.

Görülüyor ki, CMK., sanığın önceki beyanlarının duruşmada okunabilmesi için, hangi makamlar önünde alınması gerektiğini belirtmiş ve md. 148/4'te de, müdafi hazır bulunmaksızın kolluk tarafından alınan ifadelerin hakim veya mahkeme huzurunda tekrarlanmadıkça hükme esas alınamayacağını düzenlemiștir. O halde, 5271 sayılı CMK.'nın 213 ve 148/4 maddelerini birlikte düşünmek ve bir değerlendirme yapmak gerekmektedir.

Çalışmamızın konusunu, gözaltında alınan ifadenin soruşturma ve kovuşturma evrelerindeki önemi ile delil değeri oluşturmaktadır. 
Şüphelinin savcılıkta veya kollukta alınan ifadesi, soruşturma evresinde kamu davasının açılıp açılmaması bakımından önem taşımaktadır. İlk kısımda, soruşturma evresinde bir "delil aracı" olan ifadenin "delil" olarak nitelendirilebileceği, bir başka deyişle, Cumhuriyet savcısının kamu davasını açmak amacıyla, isnat konusu suçla ilgili şüphesini yenebilmesi için, ifadeyi değerlendirebilmesi ve delil değeri tanıyabilmesi üzerinde durulacaktır.

Bunun yanısıra, soruşturma evresinde elde edilen ifadenin, gerek isnat edilen suça, gerekse isnat edilen suç dışında başka bir suça ilişkin diğer delil araçlarına ulaşmadaki önemi incelenecektir.

İfadenin soruşturma evresindeki önemi ve delil değeri tartışılıp, bir sonuca varıldıktan sonra, bu ifadenin kovuşturma evresindeki delil değeri ele alınacaktır.

İkinci kısımda, esas olarak CMK. ile getirilen ve sanığın Cumhuriyet savcısı tarafından veya müdafii huzurunda kollukça alınan ifadelerinin, md. 213 ve md.148/4 hükümleri çerçevesinde delil değeri tartışılacaktır.

Bilindiği üzere, bir delil aracının delil olarak nitelendirilebilmesi için yetkili makam tarafından değerlendirilmesi gerekmektedir. Bir delil aracı, her muhakeme evresinde ayrı ayrı değerlendirilip, delil değerini haiz olur. $\mathrm{Bu}$ nedenle, soruşturma evresinde kamu davasını açmada delil olarak kullanılan ifadenin, kovuşturma evresinde de değerlendirilip değerlendirilmeyeceği tartışılacak ve bir sonuca varılacaktır.

\section{I- Soruşturma Evresinde İfadenin Önemi ve Delil Değeri}

\section{A- Soruşturma Evresinde Delil Kavramı}

Soruşturma evresi, bir suçun işlendiğinin öğrenilmesi ile başlamaktadır. $\mathrm{Bu}$ evrede, bir suçun işlenip işlenmediği, işlenmişse suçun faillerinin kim veya kimler olduğunu belirlemeye yönelik faaliyetler yapılır. Soruşturma evresinde amaç, kamu davasının açılmasına gerek olup olmadığının araştırılmasıdır ${ }^{1}$. CMK. md. $2 / 1$ - (e) bendinde soruşturma evresi

${ }^{1}$ Öztürk, Bahri - Erdem, Mustafa R., Uygulamalı Ceza Muhakemesi Hukuku, 11. Baskı, Ankara 2007, s. 694 vd.; Centel, Nur - Zafer, Hamide, Ceza Muhakemesi Hukuku, 5. Bası, İstanbul 2008, s. 81-82; Demirbaş, Timur, "Soruşturma Evresinde Şüphelinin İfadesinin Alınması ve Müdafilik", LHD, Y. 3, S. 32, Ağustos 2005, s. 2872; Öztürk, Bahri, Uygulamalı Ceza Muhakemesi Hukuku, 3. Baskı, Ankara 1995, s. 552; Öztürk, Bahri, Ceza Muhakemesi Hukukunda Koğuşturma Mecburiyeti (Hazırlık Soruşturması), Ankara 1991, s. 49; Çağlayan, M. Muhtar, "Hazırlık Soruşturması Yapılırken Gözönünde Tutulması Gereken Önemli Noktalar Üzerinde Bir İnceleme”, AD 1979, S. 3-4, s. 162 vd.; Özgen, Eralp, Ceza ve Ceza Muhakemesi Hukuku Bilgisi, Eskişehir 1988, s. 191 vd;; Cihan, Erol - Yenisey, Feridun, Ceza Muhakemesi Hukuku, 3. Tıpkı Basım, İstanbul 1998, s. 329; Demirbaş, Timur, "Hazırlık Soruşturmasında Müdafiilik", CMUK Sempozyumu İnsan Hakları Avrupa Sözleşmesi ve Avrupa İnsan Hakları Mahkemesi Kararları Karşısında 70. Yıldönümünde Ceza Muhakemeleri Usulü Kanunu (9 Nisan 1999 - İstanbul), İstanbul 1999, s. 91; Kantar, Baha, Ceza Muhakemeleri Usulü, Ankara 1957, 
tanımlanmıştır. Buna göre soruşturma, "Kanuna göre yetkili mercilerce suç şüphesinin öğrenilmesinden iddianamenin kabulüne kadar geçen evreyi" ifade eder. Bu amaçla, basit şüpheden kuvvetli şüpheye doğru gidilmesinde, uyuşmazlık konusu olayı temsil eden, akla, mantığa ve maddi gerçeğe uygun her türlü ispat gereci ${ }^{2}$ önemli rol oynar ${ }^{3}$.

İspat gereçleri, suç teşkil ettiği iddia edilen olayın çözülerek, ispata ulaşılması için ihtiyaç duyulan gereçlerdir. Geçmişte olup bitmiş bir olayın, muhakeme evrelerinde yeniden yaşanmasını sağlayan bu gereçler olmadan, olayın çözüme kavuşturulması imkânsızlaşmaktadır ${ }^{4}$.

İşte olayı temsil eden ve çözüme kavuşturulmasını sağlayan ispat gereçlerine "delil" denir. İspat gereçleri, aşağıda açıklanacak olan delil kaynağı, delil aracı ve delil kavramlarını kapsar şekilde kullanılacaktır5.

Bir ispat gerecinin delil niteliğini haiz olabilmesi için, yetkili makamca doğruluğuna kanaat getirilmesi gerekmektedir. Değerlendirme faaliyetinde, bir ispat gerecinin geçtiği bir takım aşamalar mevcuttur ${ }^{6}$. Kanunumuz, aşağıda farkları belirtilecek olan kavramların tümüne "delil" adını vermekte; ayrıntılı ve sistemli bir sınıflandırma öngörmemektedir.

Muhakeme makamlarının algılamasının malzemesini oluşturan veya konusunu teşkil eden veya bu makamlara incelenecek malzeme ya da bilgi sunan, dış dünyaya ait bir gerçeklik olan varlık "delil kaynăğ” olarak adlandırılmaktadır. Delil kaynağı, muhakeme makamları tarafından işlenmemiş bir malzeme veya muhakeme makamlarına ifade veren kişidir ${ }^{7}$.

Muhakeme faaliyeti boyunca, bir delil kaynağının, söz konusu makamların inceleme ve algılamasına sunulması, onu bir "delil aract" haline

s. 165 vd.; Bıçak, Vahit, Avrupa Birliği İle İlişkilerin Hazırlık Soruşturmasına Etkisi, http://www.bilkent.edu.tr/\%7Evahit/ar3.htm, Atıf Tarihi: 20.11.2007, s. 2 vd.; Toroslu,

Nevzat - Feyzioğlu, Metin, Ceza Muhakemesi Hukuku, Ankara 2006, s. 255.

2 İspat gereci hakkında ayrıntılı bilgi için bkz. Feyzioğlu, Metin, Ceza Muhakemesi Hukukunda Tanıklık, Ankara 1996, s. 2-3.

${ }^{3}$ Centel - Zafer, s. 211-214; Koca, Mahmut, "Ceza Muhakemesi Hukukunda Deliller", CHD, Y. 1, S. 2, Aralık 2006, s. 212 vd.; Eryılmaz, M. Bedri, "Kolluğun Yetkileri Açısından Ceza Muhakemeleri Usulü Kanunu (CMUK) ile Yeni CMUK Tasarısının Düşündürdükleri”, ABD 2000, C. 57, S. 1, s. 72; Öztürk, Bahri, Yeni Yargıtay Kararları Işığında Delil Yasakları, AÜSBF Yayınları, Ankara 1995, s. 4 vd.

${ }^{4}$ Feyzioğlu, Ceza Muhakemesi Hukukunda Tanıklık, s. 2-3; Kunter, Nurullah, Muhakeme Hukuku Dalı Olarak Ceza Muhakemesi Hukuku, 9. Bası, İstanbul 1989, s. 585; Kunter, Nurullah - Yenisey, Feridun - Nuhoğlu, Ayşe, Muhakeme Hukuku Dalı Olarak Ceza Muhakemesi, 14. Bası, İstanbul 2006, s. 592; Koca, Ceza Muhakemesi Hukukunda Deliller, s. 212 vd.

${ }^{5}$ Feyzioğlu, Ceza Muhakemesi Hukukunda Tanıklık, s. 26.

${ }^{6}$ Feyzioğlu, Ceza Muhakemesi Hukukunda Tanıklık, s. 24.

${ }^{7}$ Feyzioğlu, Ceza Muhakemesi Hukukunda Tanıklık, s. 24. 
getirecektir ${ }^{8}$. Gerçekten bir delil kaynağının, inceleyecek ve değerlendirecek olan yetkili makama sunulmasıyla, bir başka ifade ile söz konusu makamın, o ispat gerecinden haberdar olmasının sağlanmasıyla delil kaynağı, delil aracı niteliğini kazanır.

Delil kaynağı - delil aracı ayırımı, özellikle beyanlar bakımından önemlidir. Beyan delil aracında, yetkili makamın algılamasına sunulmadan önce bir aşama bulunmamaktadır. Beyan delil aracının kaynağı, onu sunan kişidir. Delil kaynağı, beyanını sunduğu anda, bu beyanı delil aracı halini almaktadır'.

Bir delil kaynağı, delil aracı haline geldikten sonra, gerçeği temsil etmesi şartıyla kullanıldığı evrede, yetkili makamın şüphesini yenmesini gerekli olan ölçüde sağlıyorsa, o evre için "delil” niteliğini kazanacaktır"

Soruşturma evresindeki çalışmaları yürüten ve bu çalışmaların tüm sorumluluğunu üstlenen makam, savcılık makamıdır ${ }^{11} . \mathrm{O}$ halde, muhakemenin soruşturma evresinde yetkili makamın, yani Cumhuriyet savcısının gerektiği oranda şüphesini yenmesini sağlayan bir ispat gereci, "delil" olarak adlandırılacaktır. Ancak delil olma niteliği, soruşturma evresi için geçerlidir. Soruşturma evresinde delil niteliğini kazanmış olan ispat gereci, bir sonraki evrede yetkili makam tarafından inceleninceye kadar bir delil kaynağı niteliğinde olacaktır ${ }^{12}$.

Ceza muhakemesinde amaç, maddi gerçeğe ulaşmak olduğundan herşey delil aracı olarak kabul edilir. Bir başka ifadeyle, ceza muhakemesinde "delil aracı serbestliği ilkesi”'13 geçerlidir. Söz konusu ilke, vicdani kanaat ile ilgili bir kavramdır. Vicdani delil sistemi ile kastedilen, hem delil araçlarının serbestliği, hem de delil araçlarının değerlendirilmesi serbestliğidir ${ }^{14}$. Herşeyin delil aracı olabileceği bir sistemde, delil araçları vicdani kanaate göre değerlendirilecek ve delil niteliğini kazanabileceklerdir. Delil araçları,

\footnotetext{
${ }^{8}$ Bir delil kaynağının, delil aracı haline gelmesi için, hukuka uygun şekilde elde edilmesi şart değildir. Delil kaynağı, muhakeme makamlarının algılama ve incelemesine sunulmak suretiyle delil aracı niteliğini kazanacağından, hukuka aykırı olarak elde edilmesine rağmen söz konusu makamlar tarafından incelenerek delil aracı haline getirilebilir. Hukuka aykırı elde edilmiş bir ispat gerecine delil aracı değerlendirme yasağı uygulanmalı ve hiçbir surette delil değeri kazandırılmamalıdır. Feyzioğlu, Ceza Muhakemesi Hukukunda Tanıklık, s. 24 dipnot 45.

${ }^{9}$ Feyzioğlu, Ceza Muhakemesi Hukukunda Tanıklık, s. 25; Kunter, s. 585.

${ }^{10}$ Feyzioğlu, Ceza Muhakemesi Hukukunda Tanıklık, s. 25.

${ }^{11}$ Toroslu - Feyzioğlu, s. 258; Öztürk - Erdem, s. 416.

12 Feyzioğlu, Ceza Muhakemesi Hukukunda Tanıklık, s. 25-26; Ünver, Yener, "Ceza Muhakemesinde İspat, CMK ve Uygulamamız”, CHD, Y. 1, S. 2, Aralık 2006, s. 106.

${ }^{13}$ Delil araçlarının serbestliği ilkesi için bkz. Yurtcan, Erdener, Ceza Yargılaması Hukuku, 7. Bask1, İstanbul 1998, s. 46; Kunter, s. 586; Ünver, Ceza Muhakemesinde İspat..., s. 107.

14 Kunter, s. 586; Kunter - Yenisey - Nuhoğlu, s. 593; Koca, Ceza Muhakemesi Hukukunda Deliller, s. 208-209; Öztürk - Erdem, s. 394.
} 
olayın bütününü veya bir kısmını zihnimizde yeniden canlandıracak olan ispat gereçleri olduğundan, olayın oluş biçiminin sübuta erdirilmesinde önemli rol üstlenmektedirler ${ }^{15}$.

Deliller şüphenin yenilmesinde kullanıldığg için, belirli özelliklere sahip olmalidirlar $^{16}$.

Deliller, öncelikle "gerçekçi" olmalıdır. Bununla ifade edilmek istenen, yetkili makama sunulan ispat gerecinin, elle tutulabilen, dış dünyamıza ait, gerçeğin bir parçasını oluşturmasıdır. Ancak, gerçekçi olan bir ispat gereci beş duyumuzla algılanabililir ${ }^{17}$.

Deliller, gerçeği “akla uygun” olarak ifade edebilen ispat gereçleri olmalıdır. Maddi gerçeğe ulaşmada yol, akla ve mantığa uygun olarak hareket etmekten geçtiğine göre, delillerin de akılcı olmaları kaçınılmazdır ${ }^{18}$.

Delillerin olmazsa olmaz özelliği, "olayı temsil” etmesidir. Şüphesiz, olayın bir parçasını oluşturmayan delil aracının, delil olarak değeri yoktur ${ }^{19}$.

Deliller ayrıca “hukuka aykırı olmamalı"dır. Delilin hukuka uygun olması, bir delilin sahip olması gereken en önemli özelliktir. Ceza muhakemesinde amaç maddi gerçeğe ulaşmak olduğundan, delil araçlarının hangi yollarla veya ne şekilde elde edileceğini CMK., bir yandan devletin menfaatlerini göz önünde bulundurarak, diğer yandan temel hak ve özgürlüklerin zedelenmemesine özen göstererek düzenlemiştir. Bu nedenle, delil araçlarının konu veya elde edilmesindeki yöntem ya da temel hak ve özgürlüklerin korunması yönünden yasaklanmamış olmaları gerekmektedir. Ancak bu şekilde toplanan delil araçları, delil niteliğini kazanabilir ${ }^{20}$.

Tüm bu özellikler yanında, deliller "müşterek" olmalıdır. Müştereklik, delil araçlarının içeriğinin yalnızca yargıç tarafından bilinmesini değil,

15 Feyzioğlu, Ceza Muhakemesi Hukukunda Tanıklı, s. 377; Koca, Mahmut, "Ceza Muhakemesinde Hukuka Aykırı Delilleri Değerlendirme Yasağı”, EÜHFD 2000, C. IV, S. $1-2$, s. 105 vd.

${ }^{16}$ Kunter, s. 587-590; Kunter, Nurullah - Yenisey, Feridun, Muhakeme Hukuku Dalı Olarak Ceza Muhakemesi Hukuku, 11. Bası, İstanbul 2000, s. 503-506; Centel - Zafer, s. 213-214; Koca, Ceza Muhakemesi Hukukunda Deliller, s. 212 vd.; Kunter - Yenisey Nuhoğlu, s. 594-598; Öztürk - Erdem, s. 395.

${ }^{17}$ Kunter, s. 587; Kunter - Yenisey, s. 503; Koca, Ceza Muhakemesi Hukukunda Deliller, s. 213; Kunter - Yenisey - Nuhoğlu, s. 594.

${ }^{18}$ Kunter, s. 588; Kunter - Yenisey, s. 503-504; Koca, Ceza Muhakemesi Hukukunda Deliller, s. 213; Kunter - Yenisey - Nuhoğlu, s. 594.

${ }^{19}$ Kunter, s. 590; Koca, Ceza Muhakemesi Hukukunda Deliller, s. 213; Kunter - Yenisey Nuhoğlu, s. 596.

${ }^{20}$ Kunter, s. 590-591; Koca, Ceza Muhakemesi Hukukunda Deliller, s. 213-214; Toroslu Feyzioğlu, s. 170-171; Kunter - Yenisey - Nuhoğlu, s. 596-597. 
tarafların da öğrenmesini gerektirir. Delil araçları, muhakemede ortaya konulup tartışılmakla delil niteliği kazanabilirler ${ }^{21}$.

Muhakeme süresince yapılan tüm faaliyetler iki temel sorunun çözülmesi amacıyla gerçekleştirilmektedir. Bunlar, olaya ilişkin olan maddî sorun ve hukuk kurallarının uygulanmasıyla ilgili olan hukukî sorundur ${ }^{22}$.

Geçmişte yaşanıp biten bir olayın, duruşmada oluş biçiminin sübuta erdirilmesi, ispat konusu ile ilgilidir. İspat, olayın gerçekleşmiş olduğuna dair bir kanaat elde edilmesi için yapılan faaliyettir ${ }^{23}$.

Delil araçlarının değerlendirilmesi ispatla ilgili bir faaliyet olduğundan, delil araçlarını, sübut konusunda karar vermeye yetkili olan makamların değerlendirmesi gerekir. $\mathrm{Bu}$ makamlar, soruşturma evresinde savc1lık, kovuşturma evresinde de mahkeme makamıdır ${ }^{24}$. O halde, Cumhuriyet savcısı, soruşturma evresinde delil araçlarını değerlendirecek ve onlara delil niteliği verebilecektir.

Değerlendirme faaliyetinde, gerçeği temsil ettiği sonucuna varılan her delil aracı, delil niteliğini kazanacaktır. İspata ulaşmak, bir muhakeme faaliyeti ürünüdür. Muhakeme faaliyeti sonunda şüphe yenilerek, maddi gerçeğe ulaşılır. Bu faaliyet, iddia, savunma ve yargılama makamlarının ortak bir faaliyetidir. CMK. md. 170/2'de, Cumhuriyet savcısina delil araçlarını değerlendirme yetki ve görevi verilmiştir. $\mathrm{Bu}$ maddeye göre, "Soruşturma evresi sonunda toplanan deliller, suçun işlendiği hususunda yeterli şüphe oluşturuyorsa; Cumhuriyet savcısı, bir iddianame düzenler". Maddeden anlaşılıyor ki, Cumhuriyet savcısının kamu davasının açılmasına karar verebilmesi için, toplanan delil araçlarının yeter derecede olup olmadıklarını değerlendirmesi gerekmektedir. Delil araçlarının değerlendirildiği faaliyet, muhakeme faaliyetidir. Cumhuriyet savcisının soruşturma evresi sonucunda iddianame hazırlayıp kamu davasının açılmasına dair verdiği kararda, o evre için gereken ölçüde bir ispata ulaşıldığ 1 kabul edilmelidir. $\mathrm{Bu}$ nedenle, soruşturma evresinde de, bir muhakeme faaliyeti yürütülmektedir. Muhakeme faaliyeti ispata ulaşmak amaciyla yürütüldügüunden, soruşturma evresinde "delil”in varlığını kabul etmek gerekmektedir. Zira, kanunumuz da, CMK. md. 170'de açıkça "delil" ibaresine yer vermiştir. Bundan çıkan sonuç, delilin yalnızca kovuşturma

${ }^{21}$ Ünver, Ceza Muhakemesinde İspat..., s. 119; Kunter, s. 591; Koca, Ceza Muhakemesi Hukukunda Deliller, s. 214; Kunter - Yenisey - Nuhoğlu, s. 597; Toroslu - Feyzioğlu, s. 171-172.

${ }^{22}$ Feyzioğlu, Ceza Muhakemesi Hukukunda Tanıklık, s. 377; Yurtcan, s. 258.

${ }^{23}$ Koca, Ceza Muhakemesinde Hukuka Aykırı Delilleri..., s. 109; Yurtcan, s. 258.

${ }^{24}$ Feyzioğlu, Ceza Muhakemesi Hukukunda Tanıklık, s. 28-30; Kunter, s. 631. 
evresine ait bir ispat gereci olmadığıdır. Delil araçları, şüphenin yenilmesini sağladığı her evrede delil niteliğini haizdir ${ }^{25}$.

Delil araçlarının değerlendirilmesinde iki yöntem uygulanmaktadır. Bu yöntemler birbirinden bağımsız değil, bilâkis birbirini tamamlar niteliktedir. İlk yöntem, her bir delil aracının doğruluğunun tek başına değerlendirilmesidir. Diğer yöntem ise, delil araçlarının yan yana konulması suretiyle birbirini tamamlayıp tamamlamadıklarına göre yapılan değerlendirmedir. Bu ikinci yönteme göre, delil araçları bir bütünün parçaları konumundadırlar. Olayı bir mozaik tablosu olarak düşünürsek, her bir delil aracı da bu tablonun küçük parçasını oluşturmaktadırlar ${ }^{26}$. Anlamlı bir bütün içerisinde yer bulamayan delil araçları, değerlendirme sonucunda delil değerini haiz olamayacaklardır.

Delil araçları değerlendirilirken, iki yöntemin de aynı somut olayda birbirini tamamlar şekilde uygulanması gerekir.

Bir delil aracının delil olarak değerlendirilebilmesi için, maddi gerçeğin bütününü yansıtması gerekmez. Zira, yukarıda değerlendirme yöntemlerinden bahsederken, delil araçlarını yan yana koyduğumuzda bir bütünün parçacıkları gibi düşünmemiz gerektiğini belirtmiştik. Her bir delil aracı, maddi gerçeğin bir kısmını temsil edebilir, bu parçalar yan yana geldiğinde gerçeği ortaya çıkaracaktır ${ }^{27}$.

Tek başına olayın bütününü veya bir kısmını temsil eder nitelikte olan delil araçları, diğer delil araçlarıyla yan yana konulduğunda uyumlu olmalıdır. Elde edilen tüm küçük parçaların birbiri ile uyuşması ve birbirini tamamlaması gerekir. Bir delil aracının bütün ile bağdaşmaması, olayı temsil etmemesi anlamındadır ${ }^{28}$. Olayın bir kısmını temsil etme hali, özellikle insan kaynaklı delil araçlarında önem taşımaktadır. Kaynağı insan olan delil araçları, örneğin tanık açıklamaları gerçeği tam olarak yansıtmayabilir.

25 Koca, Ceza Muhakemesi Hukukunda Deliller, s. 222; Feyzioğlu, Ceza Muhakemesi Hukukunda Tanıklık, s. 25; Feyzioğlu, Metin, Ceza Muhakemesinde Vicdani Kanaat, Ankara 2002, s. 112 dipnot 332.

Doktrinde bu konuda farklı görüşe sahip olanlar vardır. Kunter'e göre; muhakeme, davacının, davalının ve yargıcın yaptıklarından oluşan üçlü bir faaliyeti ifade eder. Kunter, muhakemeyi üç makamın da katıldığı bir faaliyet olarak nitelendirdiğinden, soruşturma evresinde hiçbir şekilde muhakeme faaliyeti yürütülmediğini düşünmektedir. Yazar, muhakeme faaliyetinin olmadığı bir evrede, ispata ulaşma da söz konusu olmadığından, soruşturma evresinde "delil" kavramına yer olmadığını ileri sürmektedir. Kunter, soruşturma evresinde elde edilen belirtileri, belgeleri veya ifadeleri "şüphe sebepleri" olarak nitelendirmektedir. Bkz. Kunter, s. 6 dipnot 9; s. 758; Kunter - Yenisey Nuhoğlu, s. 7 dipnot 9, s. 672, s. 704.

${ }^{26}$ Kunter, s. 602; Kunter - Yenisey - Nuhoğlu, s. 608-609; Feyzioğlu, Ceza Muhakemesi Hukukunda Tanıklık, s. 378-379; Centel - Zafer, s. 211; Feyzioğlu, Ceza Muhakemesinde Vicdani Kanaat, s. 141-142.

${ }^{27}$ Kunter, s. 602; Kunter - Yenisey - Nuhoğlu, s. 608.

${ }^{28}$ Kunter, s. 603; Kunter - Yenisey - Nuhoğlu, s. 608-609. 
Bütün içinde bir parçayı oluşturan delil aracının bir kısmının doğru, bir kısmının yanlış olması da mümkündür. Bu durumda, delil aracının gerçeğe uygun olan kısmı ayıklanır, gerçeğe uygun olmayanları ise değerlendirilmez. $\mathrm{Bu}$ şekilde de, her bir delil aracının gerçekle uyuştuğu kısımları dikkate alınarak, maddi olay çözülmeye çalışılır ${ }^{29}$.

Olayın bütününün delil araçları ile sabit olması, çoğu zaman mümkün olmamaktadır. Ancak, mevcut delil araçları, şüphenin yenilmesini sağlamaya yeter derecede ise, kalan boşluklar, sabit olan olayın parçalarına dayanılarak doldurulabilir. Diğer bir deyişle, bu boşlukların da doldurulması, olayın sabit görülmesi için bir ihtiyaç değildir ${ }^{30}$.

Delil araçlarını değerlendirecek olan yetkili makamın ilk önce delil aracının içeriğini öğrenmesi gerekir. Bu değerlendirme mutlaka yapılmalıdır; çünkü delil aracının olay ile bağlantısını ortaya çıkaracaktır ${ }^{31}$.

Muhakemenin hem soruşturma, hem de kovuşturma evresinde, delil araçlarını değerlendirecek olan makamların o evre için gerekli ispata ulaşması söz konusu olduğundan, ispatın derecelendirilmesi mümkün olmaktadır. Ancak, soruşturma evresinde varılacak ispat ile kovuşturma evresinde varılacak ispat, derece olarak birbirinden farklıdır. Soruşturma evresindeki şüphe derecesi, kamu davasının açılıp açılmamasına yeter oranda şüphenin yenilmesini gerektirir ${ }^{32}$. Kovuşturma evresinde ise, şüpheden arınmış olarak maddi gerçeğe ulaşılması şarttır ${ }^{33}$.

\section{B- Soruşturma Evresinde İfadenin Önemi}

\section{1- İfadenin Diğer Delil Araçlarına Ulaşmadaki Önemi}

a- İfadenin İsnadın Konusunu Oluşturan Suçla İlgili Bir Delil Aracına Ulaşmadaki Önemi

Ceza muhakemesi basit bir şüphe ile başlayan ve adım adım şüphenin yenilmesiyle sona eren faaliyetler bütünüdür. Şüphenin yenilebilmesinde, suç şüphesi altında olan kişinin, savcılıkta veya kollukta alınan ifadesi büyük önem taşımaktadır.

Kolluk, herhangi bir şekilde suç teşkil eden fiilin işlendiğine dair bir haber aldığı veya kendisi bu bilgiye ulaştığı anda hemen araştırma faaliyetlerine başlar. Zira soruşturma evresi, suç teşkil eden olayın

${ }^{29}$ Feyzioğlu, Ceza Muhakemesi Hukukunda Tanıklık, s. 381-382.

${ }^{30}$ Kunter, s. 603-604; Kunter - Yenisey - Nuhoğlu, s. 608-609.

${ }^{31}$ Kunter, s. 605; Kunter - Yenisey - Nuhoğlu, s. 609-610.

32 Yurtcan da, soruşturma evresinde ispatın mümkün olduğunu belirtmekte; Cumhuriyet savcısının bir fiilden ötürü kamu davasını açıp açmama konusunda bir karar verebilmesi için, bir ölçüde ispatın aranacağını ifade etmektedir. Yurtcan, s. 259.

${ }^{33}$ Feyzioğlu, Ceza Muhakemesi Hukukunda Tanıklık, s. 21-22, s. 382. 
kovuşturmada çözüme kavuşturulabilmesi için, gereken delil araçlarının toplandığı aşamadır ${ }^{34}$.

Cumhuriyet savcısı veya kolluk tarafından, bu aşamada şüpheli kişinin ifadesinin alınması, ele geçirilen bilgileri ayıklamak, tasnif etmek, önemli ile önemsizi ayırmak için vazgeçilmezdir. Alınan ifadeler ile soruşturma ve araştırmaların ilerlemesi sağlanmakta ve gittikçe şüphe, en azından soruşturma evresinin amiri olan Cumhuriyet savcısı bakımından azalmakta ve hatta yenilmektedir ${ }^{35}$.

İfade alma, CMK. md.147'de ayrıntılı olarak düzenlenmiştir. İfade alma, CMK. md. 147'nin öngördüğü usul izlenerek gerçekleştirilmelidir. Ayrıca, CMK. md. 148'de, ifadesi alınan kişinin özgür iradesine müdahale edici nitelik taşıyan yasak yöntemlerin ifade alınırken kullanılmaması gerektiği belirtilmiştir. Ancak kanunda gösterilen yönteme uygun olan veya yasak usullerin kullanılmadığı ifade alma işleminde tutulan tutanaklar, hukuka uygun nitelik taşır. Hukuka uygun olan ifade tutanağ 1 , kovuşturma evresi için, belli durumlar hariç, önemsiz olsa bile, soruşturma evresinde yürütülen araştırma ve soruşturma için büyük öneme sahiptir.

Hukuka uygun elde edilen ifade tutanağından hareketle, olayla ilgili bir başka delil aracına ulaşmak mümkündür. Önemli olan, ifadenin hukuka uygun yollarla elde edilmiş olmasıdır. Olaya ilişkin yeni bilgiler, soruşturmanın ilerlemesini ve hatta Cumhuriyet savcısının şüphesini yenmesini sağlayabilir.

Hukuka aykırı yollarla elde edilen ifade kullanılarak ulaşılan diğer delil araçlarının, muhakemede kullanılıp kullanılmayacağı sorunu ise tartışmalıdır. Hukuka aykırı yöntemlerle elde edilen delil araçları kullanılarak ulaşılan delil araçları, Anglo-Amerikan Hukukunda da "zehirli ağacın meyveleri" ${ }^{6}$ olarak adlandırılmaktadır. Amerikan Hukuku'nda, zehirli ağacın meyvelerinin de zehirli olduğu ve bu delil araçlarının değerlendirilemeyeceği kabul edilmektedir ${ }^{37}$. Türk doktrininde bu ilkeye, "yasak delillerin uzak veya dolayl etkisi" de denilmektedir ${ }^{38}$.

Buna karşılık Kıt'a Avrupası hukukunda bu konuda yasal düzenleme mevcut değildir. $\mathrm{Bu}$ nedenle, bu konu doktrinde tartışmalıdır. Esasen

\footnotetext{
${ }^{34}$ Öztürk, Uygulamalı Ceza Muhakemesi Hukuku, s. 552; Yurtcan, s. 140.

${ }^{35}$ Kunter - Yenisey, s. 818; Cihan-Yenisey, s. 232; Yenisey, Feridun, İnsan Hakları Açısından Arama, Elkoyma, Yakalama ve İfade Alma ve İlgili TCK - CMUK Maddeleri, AÜSBF Merkezi Yayınları, Ankara 1995, s. 118-119.

36 İngilizcesi, "Fruit of the Poisonous Tree" olarak ifade edilmektedir. Anglo-Amerikan Hukukunda "zehirli ağacın meyveleri doktrini" hakkında bilgi için bkz. Hall, Daniel E., Criminal Procedure and The Constitution, USA 1997, s. 74-75; Ünver, Ceza Muhakemesinde İspat..., s. 136 vd.; Öztürk - Erdem, s. 485.

${ }^{37}$ Hall, s. 74-75.

${ }^{38}$ Centel - Zafer, s. 700; Öztürk - Erdem, s. 485.
} 
tartışılan nokta, Türk ceza muhakemesinde yasak yöntemler sonucunda elde edilen delil araçlarının, "delil" olarak nitelendirilip nitelendirilemeyeceği ve hükme esas teşkil edip etmeyeceğidirr ${ }^{39}$.

Bir görüşe göre; hukuka aykırı yollarla elde edilen bu delil araçları, "delil" olarak nitelendirilemez ve hükme esas alınamaz ${ }^{40}$. Bu görüşü savunanlar, delil aracı değerlendirme yasağının varlığını kabul etmekle beraber, yasal dayanak konusunda kendi içlerinde farklılık göstermektedirler. Bir kısmı bunun CMK.'nın kendi düzenlemesinden kaynaklandığını ${ }^{41}$, bir kısmı ise hukuk devleti ilkesinin bir gereği olduğunu ileri sürmektedirler ${ }^{42}$. CMK. md. 217/2'de yer alan düzenleme, bu konuya açıklık getirmektedir. "Yüklenen suç, hukuka uygun bir şekilde elde edilmiş her türlü delille ispat edilebilir” hükmü, Türk ceza muhakemesi hukuku bakımından tartışmayı ortadan kaldırmaktadır. Bu hükümle, delil araçlarının elde edilişinin doğrudan ve dolaylı etkisi ayırımı yapılmamıştır. "Hukuka uygun bir şekilde elde edilmiş her türlü delil” ibaresi ile herhangi bir şekilde hukuka aykırı olmama durumları kastedilmiştir ${ }^{43}$.

Bu görüşü savunan bir kısım yazar ise, zehirli ağacın meyvelerinin de her zaman zehirli kabul edilmesinin bazen açık bir haksızlığa neden olabileceğini ileri sürmüşlerdir. Örneğin kolluk tarafından delil araçları toplanırken yapılan usulî hatalar, elde edilen "diğer delil araçlarını" değerlendirme kapsamı dışında bırakabilecektir. Bu görüşe göre, işkence dışında diğer yöntemlerle elde edilen delil araçları, ilk delil aracı hukuka aykırı olsa dahi, bu delil araçlarına devlet kendi imkânları ile ulaşabilecekse, zehirli ağacın meyvesinin zehirli olmaması gerekir ${ }^{44}$.

${ }^{39}$ Kunter - Yenisey, s. 536; Öztürk, Yeni Yargıtay Kararları Işı̆̆ında..., s. 32; Öztürk Erdem, s. 485 - 486; Keskin, Serap, Ceza Muhakemesi Hukukunda Temyiz Nedeni Olarak Hukuka Aykırılık, İstanbul 1997, s. 182; Toroslu, Nevzat, "Hukuka Aykırı Deliller Sorunu”, Prof. Dr. Hamide Topçuoğlu'na Armağan, Ankara 1995, s. 58; Yenisey, İnsan Hakları Açısından Arama..., s. 141; Demirbaş, Timur, Türk Ceza Hukukunda İşkence Suçu, Ankara 1992, s. 52; Öztürk, Ceza Muhakemesi Hukukunda Koğuşturma Mecburiyeti s. 59-60; Şahin, Cumhur, Sanığın Kolluk Tarafından Sorgulanması, Ankara 1994, s. 229-230; Odman, M. Tevfik, "Hukuka Aykırı Sekilde Elde Edilen Delillerin Kullanılma Sorunu”, İnsan Hakları Merkezi Dergisi, Kasım 1995, C. 3, S. 4, Ankara 1996, s. 25.

${ }^{40}$ Kunter - Yenisey, s. 536; Öztürk, Yeni Yargıtay Kararları Işı̆̆ında..., s. 32-33; Toroslu, Hukuka Aykırı Deliller..., s. 58; Keskin, s. 183.

${ }^{41}$ Öztürk, Yeni Yargıtay Kararları Işı̆̆ında..., s. 33; Öztürk - Erdem, s. 485-486; Öztürk, Bahri, "CMUK Reformu ve Delil Yasakları", SÜHFD 1994, C. 4, S. 1-2, s. 48.

${ }^{42}$ Keskin, s. 183.

43 Öztürk, Yeni Yargıtay Kararları Işı̆̆ında..., s. 33; Öztürk, Uygulamalı Ceza Muhakemesi Hukuku, s. 393-394; Öztürk - Erdem, s. 486-487.

${ }^{44}$ Yenisey, Feridun, "Yasak Yöntemlerle ve Hukuka Aykırı Şekilde Elde Edilen Deliller", 24.10.1994 Yargitay’da sunulan tebliğ, Savaş, Vural - Mollamahmutoğlu, Sadık, Ceza Muhakemesi Usulü Kanununun Yorumu, C. I, Madde 1-257, Ankara 1995, s. 1238. 
Buna karşın, hukuka aykırı yollarla ulaşılan diğer delil araçlarının, muhakemede kullanılabileceğini ve hükme dayanak yapılabileceğini ileri sürenler vardır. $\mathrm{Bu}$ görüşü savunanlar, yargıcın kendisi tarafından elde edilmesi olanağı bulunmayan delil araçlarını değerlendirme dışı bırakmamak zorunda olduğunu, hukuka aykırı yollarla elde edilen ifade sonucu ele geçirilen başka bir delil aracını görmezlikten gelemeyeceğini belirtmişlerdir. Yine, dolaylı elde edilen diğer delil araçlarının kullanılmamasının kabul edilmesi için, kanunda açıkça bir hükmün bulunmasının gerektiğini ileri sürmüşlerdir. $\mathrm{Bu}$ yazarlar, CMK. md. 148' in yasak yöntemler sonucunda elde edilen ifadeler için değerlendirme yasağı öngördügünü, ancak delil araçlarının dolaylı etkisine hiç değinmediğini belirtmekte ve bunların muhakemede kullanılabileceğini savunmaktadırlar. Ancak, bu tür delil araçlarının diğer delil araçlarıyla da desteklenmesi gerektiğini belirtmektedirler. Yargıç, yasak yöntemlerle elde edilen ifadeyi değerlendirme dışı bırakırken, böyle bir ifade sonucu elde edilen başka bir delil aracını görmezlikten gelemez ${ }^{45}$.

Kanaatimizce, hukuka aykırı yöntemlerin kanunda yasaklanması, insan haklarına karşı duyarlılığın bir göstergesidir. Her ne kadar CMK. md. 148 'de, açıkça hukuka aykırı delil araçlarının dolaylı etkisi yasaklanmamışsa da, yine de bu delil araçlarının muhakemede kullanılamayacağı ve hükme esas alınamayacağı sonucuna varmamız mümkündür. Hukuka aykırı delil araçlarının doğrudan etkisini yasaklama için yeterli görüp de, dolaylı etkisini bu kapsam dışında tutmak bir çelişkidir. CMUK. md. 148'in, bu konuda bir açıklık içermediğini ileri sürenler, AY. md. 2'de ifade edilen "hukuk devleti ilkesi" ve bunun ayrılmaz bir parçası olan "insan haysiyetinin dokunulmazlığı ilkesini” görmezden gelemezler.

İnsan haysiyetinin ön planda olduğu ve düzenlemelerin de bu yönde yoğunlaştığını gözardı etmek ve hukuka aykırı olarak elde edilen ifade sonucu ulaşılan diğer delil araçlarını muhakemeye taşımak ve de hüküm verirken bunları kullanmak kabul edilebilir bir anlayış değildir.

\section{b- İfadenin İsnadın Konusunu Oluşturan Suç Dışında Başka Bir Suç Teşkil Eden Fiile İlişsin Delil Araçlarına Ulaşmadaki Önemi}

Ceza muhakemesinde yapılan araştırmalar ve bu araştırmalar dâhilinde alınan ifadeler sonucunda, şüpheli kişiden, bir başka suça ilişkin bir takım bilgiler elde edilmesi de mümkündür. İfadesi alınan kişiden elde edilen bilgiler, henüz soruşturma ve kovuşturma organlarının haberdar olmadığı bir

45 İçel, Kayıhan, "Sorgulamada Hukuka Aykırılık ve Sonuçları", Savaş, Vural Mollamahmutoğlu, Sadık, Ceza Muhakemeleri Usulü Kanununun Yorumu, C. I, Madde 1-257, Ankara 1995, s. 737-738; Tosun, Öztekin, Ceza ve Medeni Muhakeme Hukuku Açısından Hukuka Aykırı Yollarla Elde Edilmiş Delillerin İspat Kuvveti, İstanbul 1976, s. 52. 
suça ilişkin olabileceği gibi, hakkında ceza muhakemesi faaliyeti yürütülen ve ifade alma işleminin yapıldığı bir başka suça ilişkin de olabilir.

Cumhuriyet savcısı veya kolluk tarafından alınan ifade sırasında, yeni bir suça ilişkin bir delil aracının elde edilmesi, ifade alma hukuka uygun şekilde yapıldığı sürece, elbette ki bir başka soruşturmanın başlamasını sağlayacaktır.

Diğer yandan, hukuka aykırı elde edilen delil araçları vasıtasıyla ulaşılan, başka bir suça ilişkin delil araçlarının kullanılıp kullanılmaması, doktrinde tartışmalı bir konudur. İfade alma, hem bir delil elde etme yöntemi, hem de bir savunma aracıdır. Bu nedenle, hukuka aykırı elde edilen ifade aracılığıyla ulaşılan başka bir suça ilişkin delil araçlarının kullanılıp kullanılmaması da, bu tartışma kapsamında değerlendirilmelidir.

Bir görüşe göre, yasak yöntemlerle elde edilen delil araçlarının, bir başka soruşturmaya başlamak için başlangıç şüphesi olarak kullanılması mutlak şekilde yasaklanırsa, haksızlıklara neden olabilecektir. Bu görüşü savunanlar, yasak yöntemlerle elde edilen başlangıç şüphesinin, anayasal bir hakkı ihlal edip etmemesi ölçütünü kullanarak bir karara varılması gerektiğini ileri sürmektedirler ${ }^{46}$.

Bir başka görüş ise, hukuka aykırı şekilde elde edilen diğer delil araçlarının, bir başka suç için soruşturmanın başlatılmasına yeter derecede başlangıç şüphesi oluşturması halinde, bu şüpheye devletin kendi olanakları ile ulaşıp ulaşmaması ihtimali üzerinde durulması gerektiğini ileri sürmüştür. Devlet, başlangıç şüphesine bütün ihtimaller dikkate alındığında, kendisinin ulaşacağını kesin olarak görüyorsa, o zaman bu ifade ve dolayısıyla başlangıç şüphesi kullanılabilecektir ${ }^{47}$.

Yine, herhangi bir koşul öngörmeksizin, kanunda bu konuda hiçbir hüküm olmadığını belirterek, söz konusu delil araçlarının, soruşturmaya başlamak için başlangıç şüphesine esas oluşturabileceğini savunanlar da vardir ${ }^{48}$.

Biz, hukuka aykırı alınan ifadeden elde edilen diğer delil araçlarının kullanılmasını, söz konusu delil araçlarının yeni bir suça ilişkin olup olmamasına göre ikiye ayırarak değerlendirmekteyiz. Bu ayırıma göre; hukuka aykırı alınan ifade vasıtasıyla, soruşturma veya kovuşturma organlarınca bilinen bir diğer suç hakkında, yeni bir delil aracına ulaşılması durumunda, bu delil aracını kullanmak mümkün değildir. Çünkü, savcının veya ifadeyi alan kolluk memurunun, isnat konusu suç dışındaki diğer suçtan haberi vardır. $\mathrm{Bu}$ suç, hakkında ceza muhakemesi faaliyeti yürütülen bir

\footnotetext{
${ }^{46}$ Kaymaz, Seydi, Uygulamada ve Teoride Ceza Muhakemesinde Hukuka Aykırı (Yasak) Deliller, Ankara 1997, s. 274.

${ }^{47}$ Sahin, Sanığın Kolluk Tarafından Sorgulanması, s. 232-233.

48 Öztürk, Ceza Muhakemesi Hukukunda Koğuşturma Mecburiyeti, s. 60-61.
} 
suçtur. Memur, ifade alma sırasında bilgisinde olan bu suça ilişkin yeni bir delil aracına ulaşmak için, hukuka aykırı yöntemler kullanabilir. Bir başka ifadeyle, memurun, başka bir suça ilişkin bilgisi olduğundan, şüpheli kişiye bu yönde baskı yapması mümkündür.

Diğer yandan, hukuka aykırı olarak alınan ifade sonucunda yeni bir suça ilişkin delil aracına ulaşılması durumunda ise, kanaatimizce bu delil aracını bir başka suç için soruşturmaya başlamakta başlangıç şüphesi olarak kullanmak mümkündür. İfade alma sırasında, Cumhuriyet savcisının veya kolluğun ortaya çıkan bu suçtan haberi yoktur. Bu nedenle, yetkili memurun, ifade alma sırasında henüz haberi bile olmadığı bir suç için, hukuka aykırı yöntem kullanarak şüphelinin iradi düşünmesini ve iradi karar vermesini etkilemesi söz konusu olamaz. İfadeyi alan memur, haberi bile olmadığı yeni bir suç için önceden kötü niyet taşıyamaz. Bu nedenle, olay dışında elde edilen delil araçlarının bir başka suçta soruşturmaya başlamak için başlangıç şüphesi olarak esas alınması mümkündür.

\section{2- İfadenin Kamu Davasının Açılmasındaki Önemi}

Daha önce de belirtildiği üzere, ceza muhakemesi soruşturma ve kovuşturma olarak iki evreden oluşur. Suç şüphesi ile başlayan soruşturma evresi, şüphenin kuvvetlenmesi sonucu kovuşturma evresiyle devam eder. Kovuşturma evresine geçilmesi, iddianamenin kabul edilmesi sonucu kamu davasının açılmasıyla olur ${ }^{49}$.

Kanunumuz kamu davasını açma yükümlülüğünü Cumhuriyet savcısına vermiştir. CMK. md. 170'e göre, Cumhuriyet savcısı toplanan deliller konusunda "yeterli şüphe" mevcut ise, iddianame hazırlayıp kamu davasını açar. Maddede delil konusunda "yeterli şüphe” ibaresine yer verilmiştir. Kanun koyucu, Cumhuriyet savcısına yeterli şüphe oluşturacak delil elde ettiği takdirde, iddianame hazırlayıp kamu davasını açma yükümlülüğü getirmiştir. $\mathrm{Bu}$ hükümle birlikte, delil araçlarının hangi dereceye geldiklerinde yeterli şüphe oluşturacak delil niteliğinde olacakları sorusu akla gelebilir. Burada, Cumhuriyet savcısı, suç şüphesi altında olan kişi hakkında kamu davasını açarken, en azından kendi içindeki şüpheyi yenmiş veya fiilin suç olduğuna dair çok az bir şüphe duyacak şekilde inanmış olmalıdır. $\mathrm{Bu}$ da "yeterli şüphe" oluşturacak delil araçlarının varlığına bağlıdır ${ }^{50}$.

Cumhuriyet savcısının, kanunen delil aracı değerlendirmeye yetkili kişi olması, onun aynı zamanda sübut konusunda bir karar verme yetkisinin de bulunması demektir. Cumhuriyet savcısının delil araçlarını değerlendirip, sübut konusunda bir sonuca varması, fiilin suç teşkil ettiğine dair var olan

49 Centel - Zafer, s. 623-624; Toroslu - Feyzioğlu, s. 267 - 268; Feyzioğlu, Ceza

Muhakemesi Hukukunda Tanıklık, s. 21; Öztürk - Erdem, s. 723.

${ }^{50}$ Feyzioğlu, Ceza Muhakemesi Hukukunda Tanıklık, s. 21-22. 
şüphesini yendiğini göstermektedir. Cumhuriyet savcısının kamu davasını açmak için, kendi açısından tamamen şüphesini yenmesi veya çok az bir şüphe duyması gerekir. Soruşturma evresinde Cumhuriyet savcısı açısından şüphe tamamen yenilse de, sübut konusunda, her zaman şüphe vardır. Kovuşturma evresi sonucunda, mahkemenin vermiş olduğu kararda ise artık hiçbir şüphe mevcut değildir ${ }^{51}$.

Şüphenin yenilmesi konusu ispatla ilgili olduğundan, yukarıda da açıklandığı üzere, ispatın derecelendirilmesi gereklidir. Cumhuriyet savcısının soruşturma evresindeki ispatı, şüphe içeren bir ispattır; kovuşturma evresinde ise şüphenin söz konusu olmadığı bir ispata ulaşılır ${ }^{52}$.

Cumhuriyet savcısının soruşturma evresindeki ispatı, mâkul bir şüphe içerebilir. CMK. md. 170'te, Cumhuriyet savcısının kamu davası açma mecburiyeti, "yeterli şüphe” şartına bağlanmıştır. Delil araçları, kamu davasını açmak için yeter derecede ise, bir başka ifadeyle kişinin mahkûm olmasi beraat etmesine oranla daha kuvvetli bir ihtimal ise, Cumhuriyet savcısı kamu davasını açmak zorundadır ${ }^{53}$. Cumhuriyet savcısının da, bu aşamada yanılma payı elbette ki vardır. İspatın derecelendirilmesi konusunda, soruşturma evresinde Cumhuriyet savcısının yoğun bir şüpheye ulaştığını söylemek mümkündür ${ }^{54}$.

Diğer yandan, soruşturma evresinde sübut konusunda Cumhuriyet savcısının yeterli bir şüphe duyması halinde dahi, kamu davasını açma yükümlülügüüün öngörülmesiyle, "şüpheden sanık yararlanır" ilkesinin en azından bu safhada uygulanmasının mümkün olmadığı sonucu ortaya çıkmaktadır. Zira, Cumhuriyet savcısının bu hususta en ufak bir şüphe duyması halinde, bunu sanığın lehine yorumlaması ve kamu davası açmaması gerekir. Oysa ki, Cumhuriyet savcısı toplanan delil araçlarıyla kendi açısından şüphesini yendiğine kanaat getirirse, kamu davasını açmak zorundadır. Ancak kamu davasını açarken dahi, Cumhuriyet savcısının çok az bir şüphe duyması mümkündür. Bu durumda en ufak şüphe payını da çok dikkatli takdir etmesi gerekmektedir ${ }^{55}$.

Cumhuriyet savcısının soruşturma evresinde elde ettiği delil araçları, onun sübut konusunda bir karar vermesini sağlayacaktır. Nitekim, soruşturma evresinde alınan ifadeler, suç işlendiğine dair bir ipucu, bir

51 Feyzioğlu, Ceza Muhakemesi Hukukunda Tanıklık, s. 21-22; Feyzioğlu, Ceza Muhakemesinde Vicdani Kanaat, s. 112 vd.

52 Feyzioğlu, Ceza Muhakemesi Hukukunda Tanıklık, s. 21-22; Feyzioğlu, Ceza Muhakemesinde Vicdani Kanaat, s. 112 vd.

${ }^{53}$ Feyzioğlu, Ceza Muhakemesi Hukukunda Tanıklık, s. 21-22; Öztürk, Ceza Muhakemesi Hukukunda Koğușturma Mecburiyeti, s. 144-145.

${ }_{55}^{54}$ Feyzioğlu, Ceza Muhakemesi Hukukunda Tanıklık, s. 22.

${ }^{55}$ Feyzioğlu, Ceza Muhakemesi Hukukunda Tanıklık, s. 23; Öztürk, Ceza Muhakemesi Hukukunda Koğuşturma Mecburiyeti, s. 145. 
ayrıntı öğrenebilmek için yapılan araştırma faaliyetleridir ${ }^{56}$. Şüphelinin, savcı veya kolluk tarafından alınan ifadeleri, soruşturma evresinde kamu davasını açma konusunda, Cumhuriyet savcısına yardımcı olan bir delil aracıdır. Savcı, şüphelinin ifadesi doğrultusunda kendi içindeki şüpheyi giderici bir ipucu bulursa, soruşturma evresinde ispata ulaşmış demektir.

İspatın derecelendirilmesinden hareketle, ifadelerin, soruşturma evresinde sübuta yani iddianame düzenlenip de kamu davasının açılıp açılmamasına karar vermekte, birer delil olduklarından şüphe edilmemesi gerekir.

Diğer yandan, hukuka aykırı olarak alınan ifadelerin, kamu davasını açmak için Cumhuriyet savcısı tarafından "delil" olarak değerlendirilip değerlendirilmeyeceği sorunu ortaya çıkmaktadır. Ifade alma sırasında, ifade alan memurun hukuka aykırı davranışlarını iki başlık altında incelemek mümkündür:

İlk hukuka aykırılık hali, ifade alan memurun, kişiye haklarını hatırlatmadan, onun ifadesini alması şeklinde ortaya çıkmaktadır. Ceza muhakemesinde suç şüphesi altında olan kişinin bir takım haklara sahip olduğu kuşkusuzdur. Şüpheli kişinin sahip olduğu bu hakları kullanabilmesi için, kendisine bildirilmesi gerekir. Bir hakkın bilfiil kullanılması, ancak onun bilinmesi ile mümkündür. Bilinmeyen haklar, herhangi bir anlam ifade etmemektedir $^{57}$.

Bu bildirimin, CMK. md. 90/4'te yakalama anında ve md. 147'de de ifade alma sirasinda yinelenmesi gerekmektedir. Kanunda yer alan hakların bildirimi, hem yakalama anında, hem de ifade alma sirasinda gerçekleştirilecektir. Bir başka deyişle, şüpheli kişi ile ilk temasa geçildiği anda ve daha sonra ifade alma sırasında kendisine sahip olduğu haklar bildirilmelidir. Hakların bildiriminin temelini oluşturan Miranda Kararında da, kişiye yakalandığı anda haklarının bildirilmesi zorunluluğu kabul edilmiştir ${ }^{58}$.

Kanun koyucu, hakların bildirimini soruşturma ve kovuşturma görevlilerine yüklemiştir (CMK. md. 90/4 ve md. 147). İşte soruşturma

${ }^{56}$ Toroslu - Feyzioğlu, s. 258; Kunter - Yenisey, s. 818; Cihan - Yenisey, s. 232.

${ }^{57}$ Öztürk, Yeni Yargıtay Kararları Işı̆̆ında..., s. 12; Kaymaz, Uygulamada ve Teoride..., s. 31; Şahin, Cumhur, "Yargıtay Kararları Işı ğında Hukuka Aykırı Deliller ve Değerlendirilmesi Sorunu", EÜHFD 1997, C. 1, S. 1, s. 92.

${ }^{58}$ Öztürk, Bahri, "CMUK Reformu ve Uygulama”, Yeni Türkiye, Temmuz - Ağustos 1996, Y. 2, S. 10, s. 600 vd.; Öztürk, Uygulamalı Ceza Muhakemesi Hukuku, s. 386; Öztürk, Yeni Yargıtay Kararları Işı̆̆ında..., s. 12 vd.; Yenisey, İnsan Hakları Açısından Arama..., s. 77. 
evresinde görevlilerin hakları bildirmesi "aydınlatma yükümlülüğü̈"59 olarak adlandırılmıştır. Bu yükümlülüğe göre, soruşturmayı yapan görevliler, şüpheli hakkında bir işlem yapmadan önce kendisine isnat edilen suçu anlatmak ve yakınlarına haber verme, konuşmama ve müdafiden yararlanma hakkı olduğunu bildirmek zorundadırlar.

Aydınlatma yükümlülüğg̈, ifade alma sırasında da düzenlendiğinden, bu yükümlülüğe aykırılık ayrı bir delil aracı elde etme yasağı olmaktan çıkarılmış, ifade alma sırasında söz konusu olan delil aracı elde etme yasaklarından sayılmıştı́r ${ }^{60}$.

CMK. md. 147'deki düzenlemede, bu yükümlülüğün ihlal edilmesi halinde, sonuçların ne olacağı belirtilmemiştir. Bu durumda, CMK. md. 147 ile 4709 sayılı Kanunla AY. md. 38'e eklenen hüküm ve ayrıca CMK. md. 217/2'yi birlikte düşünmemiz gerekir ${ }^{61}$.

Daha önce de açıkladığımız gibi, CMK. md. 170' de “delil” ibaresinden söz edilmektedir. Kanunumuz açıkça, soruşturma evresinde "delil" olabileceğini öngörmüştür. 4709 sayılı Kanunla AY. md. 38'e eklenen fıkraya göre, "Kanuna aykırı olarak elde edilmiş bulgular, delil olarak kabul edilemez". Anayasa hükmü açıkça, soruşturma veya kovuşturma evresi ayırımı yapmaksızın, kanuna aykırı olarak elde edilen delil araçlarının delil olarak nitelendirilemeyeceğini belirtmiştir. $O$ halde, ifade alma işleminde hakları ögrretilmeksizin alınan ifadeler, Anayasa'nın hükmü gereğince delil niteliğini haiz olamayacaktır.

Aynı sonuca CMK. md. 217/2'yi kullanarak da ulaşmak mümkündür. Şöyle ki, CMK. md. 217/2'de, "Yüklenen suç, hukuka uygun bir şekilde elde edilmiş her türlü delille ispat edilebilir" hükmüne yer verilmiştir. CMK. md. 90/4 ve md. 147'deki aydınlatma yükümlülüğünü yerine getirmemek, CMK. md. 217/2' de öngörülen genel değerlendirme yasakları kapsamındadır. Yüklenen suçun, hukuka uygun bir şekilde elde edilmiş delille ispat edilmesi gerekmektedir. Hukuka aykırı olarak elde edilmiş delil araçları ispat için kullanılabilecek ve hükme esas alınabilecek delil niteliğini haiz olamaz. Bu nedenle, CMK. md. 217/2'de dolaylı olarak, aydınlatma yükümlülüğünün yerine getirilmemesiyle alınan ifadelerin hukuka uygun olmadığ 1 ve ispat değerine sahip olamayacağı belirtilmiştir. Maddede belirtilen, hukuka uygun

59 Aydınlatma Yükümlülüğü hakkında ayrıntılı bilgi için bkz. Kaymaz, Seydi, “Aydınlatma Yükümlülüğünün İhlali Sebebiyle Sözkonusu Olan Yasak Deliller”, YD, Temmuz 1997, C. 23, S. 3, s. 280-300.

60 Öztürk, CMUK Reformu ve Uygulama, s. 600 vd.; Öztürk, Uygulamalı Ceza Muhakemesi Hukuku, s. 386; Öztürk - Erdem, s. 479-480; Öztürk, Yeni Yargitay Kararları Işı̆̆ında..., s. 12 vd.

61 Öztürk, CMUK Reformu ve Uygulama, s. 600 vd.; Öztürk, Uygulamalı Ceza Muhakemesi Hukuku, s. 386; Öztürk - Erdem, s. 480; Öztürk, Yeni Yargitay Kararları Işı̆̆ında..., s. $12 \mathrm{vd}$. 
bir şekilde elde edilen delille ispat edebilme, kovuşturma evresinde hukuka aykırı delil araçlarının değerlendirilemeyeceği anlamını taşımaktadır. Ancak, CMK. md. 217/2 bir kural hükümdür. Bu nedenle kovuşturma evresi için geçerli olan bu kural hükmü, soruşturma evresinde de kıyasen uygulamamız mümkündür. Zira, "delil”, hem soruşturma, hem de kovuşturma evrelerine ait bir kavramdır. O halde, soruşturma evresinde de hukuka aykırı şekilde elde edilen delil araçları, değerlendirme dışında tutulacaktır. Bir başka ifadeyle, Cumhuriyet savcısı, soruşturma evresinde hukuka aykırı delil araçlarını değerlendirmeyecek, hukuka uygun delil araçlarıyla şüphesini yenmeye çalışacaktır. Sonuç olarak, bu hükmün kıyasen soruşturma aşamasında da uygulanmasıyla, CMK. md. 147 uyarınca kolluk görevlileri tarafından hukuka aykırı alınan ifadeler, kamu davasının açılıp açılmamasında herhangi bir değere sahip olamayacaklardır.

İfadelerin hukuka aykırı olarak elde edilmesinin ikinci hali, yasak yöntemler kullanılarak alınmasıdır. CMK. md. $148^{\prime}$ de elde edilen bu ifadelerin, hukuka aykırı bir delil aracı oluşturduğu belirtilmiştir. Yasak yöntemler sonucu elde edilen ifade, kanunda belirtilen açık hükmü ihlal etmekle beraber, aynı zamanda suç şüphesi altında olan kișinin haklarını da değersiz kılmaktadır ${ }^{62}$.

CMK. md. 148'in amacı, hukuka aykırı yollarla ifade alınmasını önlemek ve soruşturma görevlilerinin ifadesi alınan kişi üzerinde zor kullanmasına engel olmaktır. Bu amaç doğrultusunda, CMK. md. 148/3, ifadesi alınan kişinin rızasının olması halinde dahi, bu ifadelerin delil değerine sahip olmayacağı hükmüne yer vermiştir. CMK. md. 148 hükmü ile korunmak istenen, özgür irade ve insan haysiyetidir ${ }^{63}$. Bu nedenle, kişinin rızası olması halinde dahi, yasak yöntemlerle alınan ifadelerin kullanılması mümkün değildir. Zira, yasak yöntemler kullanılarak alınan ifadeler "yok" hükmünde olduğundan, hukuk düzeninde hiç var olmamış bir delil aracının bir kanaate ulaşmada esas alınması da düşünülemez ${ }^{64}$.

Diğer yandan, CMK. md. 148, ifade alma veya sorgu sirasındaki hukuka aykırı yöntemlerle alınan ifadeler açısından değerlendirme yasağı öngörürken, CMK. md. 217/2 ise, muhakeme süresince soruşturma ve kovuşturma organlarının hukuka uygun olarak elde ettikleri delil araçlarının ispat değeri taşıyacağını belirtmiştir. Bu durumda, CMK. md. 217/2'nin, md.

62 Özgen, Eralp, “İşkence ve İnsanlık Dışı Davranışlara Karşı Birleşmiş Milletler Andlaşması", TBBD, Eylül 1988, S. 2, s. 224.

${ }^{63}$ Koca, Ceza Muhakemesinde Hukuka Aykırı Delilleri..., s. 127.

${ }^{64}$ Hafızoğulları, Zeki, Hukuka Aykırı Elde Edilen Deliller Meselesi, Yeni Türkiye, Temmuz - Ağustos 1996, Y. 2, S. 10, s. 640; Yenisey, Yasak Yöntemler..., s. 1235; Demirbaş, Timur, Sanığın Hazırlık Soruşturmasında İfadesinin Alınması, İzmir 1996, s. 268; Koca, Ceza Muhakemesinde Hukuka Aykırı Delilleri..., s.131. 
148 'i de içine alan bir değerlendirme yasağ öngördüğünü söyleyebiliriz ${ }^{65}$. Bunun dışında, AY. md. 38'e eklenen hüküm, her iki değerlendirme yasağını içine alacak şekilde geniş olarak düzenlenmiştir.

Kanunumuzda her iki hüküm de yer aldığından, CMK. md. 217/2, md. 148 dışında kalan hukuka aykırılık bakımından geçerli olacaktır. Bu durumda, Kanunda, biri özel biri de genel olmak üzere iki değerlendirme yasağının düzenlendiği söylenebilir ${ }^{66}$.

Görüldüğü gibi, her iki halde de, şüpheli kişinin gerek hakları bildirilmeden, gerekse yasak yöntemler kullanılarak alınan ifadesi, Cumhuriyet savcısı bakımından iddianame hazırlayıp kamu davasını açmak için bir "delil" olarak nitelendirilemez.

\section{II- Kovuşturma Evresinde İfadenin Delil Değeri}

\section{A- Genel Olarak}

Muhakeme faaliyeti, soruşturma ve kovuşturma olmak üzere iki evreden oluşmaktadır. İfade alma, soruşturma evresinde savcılık veya kolluk tarafından gerçekleștirilen bir araștırma faaliyetidir. Bu evrede alınan ifadeler ve toplanan diğer delil araçları, en azından Cumhuriyet savcısının şüphesini giderici nitelikte ise, iddianame hazırlanır ve kamu davasının açılmasına karar verilir. Önceden belirtildiği gibi, şüphelinin mahkum olma ihtimalinin beraat etmesine oranla daha kuvvetli olması ve bu durumun delil araçları ile desteklenmesi halinde "yeterli şüphe"nin olduğuna kanaat getirilir. Yeterli şüphenin var olmasıla iddianame hazırlanır ve bunun kabulü ile kamu davası açılır. Kamu davasının açılması, kovuşturmanın başlaması demektir ${ }^{67}$.

Kovuşturma evresinin hazırlayıcısı niteliğinde olan soruşturma evresinde elde edilen delil araçları, Cumhuriyet savcısı tarafından bir değerlendirme süzgecinden geçirilir. Ancak, soruşturma evresindeki delil araçları, yalnızca kamu davasının açılıp açılmaması konusunda bir karar vermek için kullanılır. Kovuşturma evresinde, hazırlık döneminde toplanan delil araçlarının kullanılması, yargıç önünde tekrar ortaya konulması ve tartışılması ile mümkündür (CMK. md. 217/1). Kovuşturma evresinde delil araçlarının doğrudan doğruyalığı ilkesi gereği, muhakeme organlarının dosyadaki yazılı belgeden değil, doğrudan o belgenin sahibi olan kişinin

65 Bıçak, Vahit, İnsan Hakları İhlallerinde Yönelimler: Baskıdan Hileye, http://www.bilkent.edu.tr/\%7Evahit/ar6.htm, Atıf Tarihi: 20.11.2007, s. 5; Odman, M. Tevfik, “Askeri Yargıtay’ın Hukuka Aykırı Deliller Konusunda Verdiği Kararlar”, AAD, Ocak 1996, Y. 24, S. 95, s. 16.

${ }^{66}$ Koca, Ceza Muhakemesinde Hukuka Aykırı Delilleri..., s. 125.

${ }^{67}$ Feyzioğlu, Ceza Muhakemesi Hukukunda Tanıklık, s. 20-21; Öztürk, Ceza Muhakemesi Hukukunda Koğuşturma Mecburiyeti, s. 144-146. 
ağzından sözlü olarak bilgiye ulaşmaları gerekir ${ }^{68}$. Doğrudan doğruya delil aracına ulaşmak da yeterli olmamakta, ayrıca olaya en yakın olanını, ilk elden olanını seçmek gerekmektedir ${ }^{69}$. Soruşturma dosyası, kovuşturma evresine kadar yapılan araştırmaların bir özeti ve aynı zamanda hem yargıcın, hem de tarafların duruşmaya hazırlanabilmeleri için oluşturulan ön bilgi kaynăğ $\mathrm{d}_{\mathrm{r}} \mathrm{r}^{70}$.

Doğrudan doğruyalık ilkesini, kovuşturma aşamasında delil araçlarına doğrudan ve ilk elden ulaşma olarak tanımladıktan sonra, soruşturma evresindeki delil araçlarının kovuşturmaya bir etkisi olmadığı ve delil araçlarının toplanmasının önemini azalttığı düşünülebilir. Ancak, soruşturma evresinde elde edilen delil araçlarından, duruşmada tekrar edilmesi mümkün olanların, yargıç huzurunda yeniden ortaya konulması gerekir ${ }^{71}$. Nitekim, soruşturma evresinde alınan tanık ifadesi ile yetinilmemekte, olayın tanığı olmuş kişinin duruşmada yeniden olay hakkındaki bilgilerini bizzat anlatması gerekmektedir (CMK. md. 210).

Aşağıdaki kısımlarda, kovuşturma evresinde, muhakemenin ilk aşamasında elde edilen ve bir delil aracı olan ifadenin değeri ve bu ifadenin kovuşturmaya dahil edilebileceği durumlar üzerinde durulacaktır.

\section{B- Cumhuriyet Savcısı Tarafından Alınan İfadenin Değeri}

CMK. md. 213'e göre; "Aralarında çelişki bulunması halinde; sanığın, hakim veya mahkeme huzurunda yaptığ açıklamalar ile Cumhuriyet savcısı tarafından alınan veya müdafiinin hazır bulunduğu kolluk ifadesine ilişkin tutanaklar duruşmada okunabilir".

Maddeden anlaşıldığı üzere, sanığın duruşma sırasında mahkeme huzurunda yaptığı açıklamalarla Cumhuriyet savcısı tarafından tespit edilen açıklamaları arasında çelişki varsa, önceki ifadesinin duruşmada okunması mümkündür.

Sanığın duruşmadaki sorgusu ile Cumhuriyet savcısı tarafından alınan önceki ifadesinin çelişmesi durumunda, yargıç duruşmayı keserek önceki ifadesini okuyabilir. Cumhuriyet savcısı tarafından alınan ifadeler arasında bir çelişki olması halinde, yargıç önceki ifadesini okur ve sanığı yeniden dinler. Sanık, yargıç huzurunda ikinci kez beyanda bulunur. Sanığın yargıç ya da mahkeme huzurunda yaptığı açıklamalara "sorgu" denilmektedir. Sözlülük ilkesi gereğince tutanakların duruşmada okunması ve tekrar

${ }^{68}$ Şahin, Cumhur, Ceza Muhakemesinde İspat (Delillerin Doğrudan Doğruyalığı İlkesi), Ankara 2001, s. 26.

${ }^{69}$ Şahin, Ceza Muhakemesinde İspat..., s. 32; Yurtcan, s. 46; Kunter - Yenisey , s. 943.

70 Şahin, Ceza Muhakemesinde İspat..., s. 33; Feyzioğlu, Ceza Muhakemesinde Vicdani Kanaat, s. 170-171, s. 175.

71 Şahin, Ceza Muhakemesinde İspat..., s. 33; Feyzioğlu, Ceza Muhakemesinde Vicdani Kanaat, s. 170-171, s. 175. 
açıklanması gerekmektedir. Bu durumda, duruşmanın yargıcı, gerekçesiyle beraber hangi ifadeye itibar edeceğine karar verir ve hüküm kurarken buna dayanır.

CMK. md. 213 uyarınca, sanığın önceki ve sonraki ifadeleri arasında çelişki olması halinde, savcılık tarafından alınan ifadelerin okunmasının amacı, sanığın bu çelişkiyi gidermesini sağlamaktır. Sanık, önceki ifadesi kendisine okununca üç ihtimal dâhilinde hareket edebilir: Sanık, savcılıktaki ifadesini inkâr edebilir. $\mathrm{Bu}$ halde, elimizde herhangi bir ifade kalmamaktadır. İkinci ihtimalde, sanık, savcılıktaki ifadesini kabul edebilir. $\mathrm{Bu}$ halde de "kabul ediyorum" şeklinde söylemesi yeterli değildir, tekrar sözlü olarak açıklaması gerekmektedir. Sanığın, savcılıktaki ifadesine uygun olarak tekrar açıklama yapması durumunda, artık yargıç huzurunda verdiği ifadesi geçerli olacaktır. Úçüncü ihtimalde ise, sanığın ne savcılıktakine ne kolluktakine ne de yargıç huzurunda söylediklerine uygun ifade vermesi söz konusudur. Sanık, tamamen farklı bir ifade verebilir. Bu halde de, yargıç hüküm kurarken, huzurunda verilen iki ifadeden birine, gerekçesini de göstererek dayanabilir.

$\mathrm{Bu}$ hükmün uygulanmasının diğer bir koşulu da, sanığın, zaman sürecinde yaptığı iki açıklaması arasında çelişkili ifadelerin yer almasıdır. Çelişki, sanığın önceden savcı önünde verdiği ifade ile duruşmadaki açıklamaları arasında sadece ikrar veya inkârla sınırlı değildir, farklılık bulunan her türlü çelişkiyi içermektedir ${ }^{72}$.

Şüphelinin Cumhuriyet savcılığında ifadesi alınırken susma hakkını kullanması, buna karşın duruşmadaki sorgusunda beyanda bulunması halinde bir çelişkiden bahsedilemez. Buna karşılık, önceden ikrar eden ve sonra susan sanığın çelişkili bir durum içerisinde olduğunu kabul etmek gerekmektedir. Zira Kanun, sorgu sırasındaki beyan ile Cumhuriyet savcısı önünde alınan ifade arasında çelişki bulunması halinde okunmasını ve sanığın tutumuna göre bir delil aracı niteliği kazandırılmasını öngörmektedir ${ }^{73}$.

CMK.'nın 213. maddesinden anlaşıldığı üzere, şüphelinin Cumhuriyet savcısı tarafından alınan ifadesine kovuşturma evresinde de delil değeri kazandırılmıştır. Cumhuriyet savcısı tarafından alınan ifade tutanaklarının duruşmada okunabilmesi için, bu ifadelerle mahkeme önündeki sorguda yer alan açıklamalar arasında çelişki bulunması yeterlidir ${ }^{74}$. Okumanın değeri, çelişkiyi gidermek içindir. Önceki ifade okunduktan sonra yargıç, hüküm kurarken, Cumhuriyet savcısı tarafından alınan ifadeye dayanabileceği gibi, sanığın duruşmada yaptığı açıklamalarına da dayanabilir.

\footnotetext{
${ }^{72}$ Şahin, Ceza Muhakemesinde İspat..., s. 231-232.

${ }^{73}$ Karşı görüş için bkz. Şahin, Ceza Muhakemesinde İspat..., s. 230-231.

${ }^{74}$ Centel - Zafer, s. 222.
} 


\section{C- Kolluk Tarafından Alınan İfadenin Değeri}

Kolluk tarafından alınan ifade tutanaklarının duruşmada okunabilmesi, ifade sırasında müdafiin bulunup bulunmamasına göre iki başlık altında ele alınacaktır.

\section{1- Müdafi Olmaksızın Kolluk Tarafından Alınan İfadenin Değeri}

CMK. md. 148/4'e göre, “Müdafi hazır bulunmaksızın kollukça alınan ifade, hakim veya mahkeme huzurunda şüpheli veya sanık tarafindan doğrulanmadıkça hükme esas alınamaz”.

Bu hüküm, sanığın, görülmekte olan davadan önce alınmış ifadesinin tekrarlanmasına ilişkindir. Maddeden anlaşılacağı üzere, doğrulanacak olan ifade tutanağı, müdafi bulunmaksızın "kolluk görevlileri" tarafından düzenlenmiş olan tutanaktır.

İfadenin duruşma sırasında doğrulanması, sanık tarafından aynı beyanın tekrarlanmasıdır. Doktrinde ileri sürülen ve bizim de katıldığımız görüşe göre; bu hüküm gereksizdir. Zira, sanığın yargıç veya mahkeme önünde tekrarladığı ifadeleri, artık sorgu kapsamında yapılmış açıklamalardır. Yargıç, huzurunda verilmiş olan beyanları dikkate alacaktır. Müdafi bulunmadan kolluk tarafından alınan ifadeler, duruşmada okunamayacağ gibi, hiçbir şekilde hükme de esas alınamaz. Bunun tek koşulu, ki artık sorgu sırasında yapılan açıklamalardır, sanığın yargıç veya mahkeme huzurunda bunları tekrarlamasıdır ${ }^{75}$. Diğer yandan, CMK. md. 213'te kanun koyucu, aralarında çelişki bulunması koşulu ile, sanığın duruşmada okunabilecek önceki beyanlarının hangi makamlar önünde, hangi koşullarda alınacağını düzenlemektedir. Md. 213'te, çelişki halinde, sadece müdafi huzurunda kolluk tarafından alınan ifadelerin duruşmada okunabileceği, müdafi bulunmaksızın alınan ifadelerin duruşma devresine taşınmasının ve dolayısıyla hükme esas alınmasının mümkün olamayacağı anlașılmaktadır ${ }^{76}$. Bu açıdan da bakıldığında, 148/4 hükmü gereksiz bir düzenlemedir ${ }^{77}$.

${ }^{75}$ Centel - Zafer, s. 222.

76 Ünver, kolluk tarafından tutulan ifade tutanağının md. 213 gereğince okunamayacağını anlamsız bulduğunu ve maddenin müdafi bulunmaksızın dahi kollukta alınan ifadenin okunabileceği şeklinde değiştirilmesi gerektiğini savunmaktadır. Müdafi bulunmaksızın alınan ifadelerin içeriğinin, sanık tarafından onaylanması halinde delil olarak hükme esas alınacağının düzenlenmesiyle, Kanun'un kendi içinde çeliştiğini, md. 148/4 ile md. 213'ün birbiriyle ters düştüğünü ileri sürmekte; okunamayan ifadenin hükme nasıl esas alınacağını, kollektiflik ilkesinin buna engel olduğunu belirtmektedir. Ünver, Yener, "Deliller ve Değerlendirilmesi”, LHD, Y. 3, S. 32, Ağustos 2005, s. 2903-2904; Ünver, Ceza Muhakemesinde İspat..., s. 186.

Kanaatimizce, yazar md. 148/4'te düzenlenen "sanık tarafindan doğrulanmadıkça" ifadesini, sanığın içeriği sadece onaylaması șeklinde algılamaktadır. Oysa ki, doğrulamak, sanığın yalnızca önceki ifadeleri "kabul ediyorum" şeklinde bir beyanı ile vücut bulmamaktadır. Sanığın kabul ettiği açıklamalarını, duruşmada yine tekrarlaması gerekmektedir. Bunun nedeni ise, Kanun koyucu, müdafi bulunmaksızın kolluk tarafından 
O halde, kolluk tarafından alınan ifadeler, çelişki olsa dahi müdafi önünde alınmadığı hallerde, duruşmada okunamaz ${ }^{78}$.

Kişinin, bir hukuk davasında vermiş olduğu ifadesinin, CMK. md. 148/4 anlamında duruşmada doğrulanması şartıyla hükme esas alınması mümkündür. Zira, sanığın yargıç veya mahkeme önünde sorgu kapsamında, önceki açıklamalarını tekrarlaması, yani aynı şekilde ifade vermesi söz konusudur.

$\mathrm{Bu}$ hükümden, sanığın kolluk tarafından düzenlenmiş olan ifade tutanaklarının ancak kovuşturma evresinde doğrulanması şartıyla hükme esas alınabileceği anlaşılmaktadır. Sanık tarafından duruşmada tekrarlanmayan beyanların, hükme esas alınması da söz konusu olamaz. Bir başka anlatımla, yargıç hüküm kurarken, müdafi bukunmaksızın kollukça alınan ifadeyi, sanığın duruşmada tekrarlaması şartıyla esas alabilir. Ancak dikkat edilmesi gereken nokta şudur: yargıç sanı̆̆ın müdafii bulunmaksızın kolluk tarafından tutulan ifadesine değil, duruşmada tekrarlanan açıklamalarına delil aracı değeri atfetmektedir.

\section{2- Müdafi Huzurunda Kolluk Tarafından Alınan İfadenin Değeri}

Kovuşturma evresine hâkim olan "doğrudan doğruyalık ilkesi",79 gereği, sanık duruşmada bizzat dinlenmelidir. Ancak kanun istisnaî durumlarda, sanığın duruşmada hazır olmasına rağmen, muhakemenin önceki aşamalarında vermiş olduğu ifadelerin duruşmada okunabileceğini öngörmüştür.

$\mathrm{Bu}$ hüküm, duruşmanın temel ilkelerinden biri olan doğrudan doğruyalık ilkesine bir istisna teşkil etmektedir. Çünkü duruşmada hazır olan ve bizzat açıklama yapma imkânı olan sanığın, müdafi huzurunda kolluk tarafından alınan önceki ifadeleri okunarak duruşmaya dahil edilmektedir.

CMK. md. 213'te yer alan düzenlemeye göre, kolluk tarafından alınan ifadelerin, duruşmada okunabilmesi için iki koşulun birlikte bulunması gerekmektedir: İlk koşul, kollukta alınan ifade ile mahkeme huzurundaki sorguda yapılan açıklamalar arasında çelişki bulunmasıdır. Bunun yanında bulunması gereken diğer koşul ise, kolluktaki ifade sırasında müdafiin bulunmasidir.

alınan ifadelere koşulsuz bir delil değeri tanımamaktadır; ancak duruşmada tekrarlanması şartıyla, bu açıklamalara bir delil değeri hasretmiştir.

77 Doktrinde bazı yazarlar, CMK. md. 148/4 ve md. 213'ün birlikte değerlendirilmesi ile müdafi hazır bulunmaksızın kolluk tarafından alınan ifade tutanaklarının herhangi bir delil değerine sahip olamayacağı görüşünü ileri sürmektedirler. Bkz. Koca, Ceza Muhakemesi Hukukunda Deliller, s. 216; Demirbaş, Soruşturma Evresinde Şüphelinin İfadesinin Alınmas1, s. 2880.

${ }^{78}$ Centel - Zafer, s. 222.

79 Kunter - Yenisey, “doğrudan doğruyalık" ibaresi yerine "vasitasızlık" ibaresini kullanmışlardır. Bkz. Kunter - Yenisey, s. 943-944. 
Bulunması gereken ilk koşul, sanığın yaptığı iki açıklaması arasında çelişkili ifadelerin yer almasıdır. Çelişki, sanığın önceden verdiği ifade ile duruşmadaki açıklamaları arasında sadece ikrar veya inkârla sınırlı kalmamalıdır, farklılık bulunan her türlü çelişkiyi bu kapsamda değerlendirmek gerekmektedir ${ }^{80}$.

Sanık, kolluk tarafından müdafi huzurunda alınan ifade sırasında açıklamada bulunabileceği gibi, susma hakkını da kullanabilir. İfade alma sırasında açıklamada bulunup da, duruşma sırasında susan sanığın beyanları arasında çelişki olduğunu kabul etmek ve ilk açıklamasının okunmasına karar vermek gerekmektedir ${ }^{81}$. Buna karşın, ifade alma sırasında sanık konuşmamış, susma hakkını kullanmışsa, sonradan ifade vermesi bir çelişkiye vüicut vermemektedir.

Kanunda kolluk tarafından müdafi huzurunda alınan ifade ile yargıç veya mahkeme önündeki açıklamalar arasında çelişki olması halinde duruşmada okunması açıkça öngörüldüğünden, tartışılması gereken esas sorun, okumanın değerinin ne olacağıdır.

Cumhuriyet savcılığı önünde alınan ifadelerde olduğu gibi, müdafi huzurunda kolluk tarafından alınan ifadelerin de okunmasının amacı, sanığın bu çelişkiyi gidermesini sağlamaktır. Sanık, önceki ifadesi kendisine okununca üç şekilde hareket edebilir: Sanık, kolluktaki ifadesini inkâr edebilir, kabul edebilir veya farklı bir açıklamada bulunabilir. Sanık, önceki ifadesini inkâr ederse, elimizde herhangi bir ifade kalmamaktadır. İkinci ihtimal olarak, sanık, kolluktaki ifadesini aynen kabul edebilir. Bu halde sadece "kabul ediyorum" şeklinde beyanda bulunması yeterli değildir, tekrar sözlü olarak açıklaması gerekmektedir. Üçüncü ihtimalde ise, sanığın ne savcılıktakine ne kolluktakine ne de yargıç huzurunda söylediklerine uygun ifade vermesi söz konusudur. Sanık tamamen farklı bir ifade verebilir. Bu halde de, yargıç, verilen iki ifadeden birine, gerekçesini de göstererek hüküm kurarken dayanabilir.

Görüldüğü üzere, 5271 sayılı CMK.'nın 213. maddesi, kovuşturma evresinde, müdafi huzurunda kolluk tarafından alınan ifade tutanaklarına delil aracı olma niteliği tanımıştır. Şöyle ki, yargıç hüküm kurarken, gerekçesini göstermek koşuluyla, sanığın müdafi huzurunda kollukça alınan ifadesine dayanabileceği gibi, duruşma sırasında yaptığı açıklamalara da dayanabilir.

\footnotetext{
${ }^{80}$ Şahin, Ceza Muhakemesinde İspat..., s. 231-232.

${ }^{81}$ Şahin, önceden ikrar eden ve sonra susan sanığın çelişkili bir durum içerisinde olduğunu kabul etmemekte ve bu ifadelerin duruşmaya dahil edilmesinin mümkün olmadığını belirtmektedir. Bkz. Şahin, Ceza Muhakemesinde İspat..., s. 230-231.
} 


\section{D- İfade Tutanağının Hukukî Niteliği}

Soruşturma evresinden kovuşturma evresine taşınan önceki ifade tutanaklarının niteliği son derece tartışmalı bir konudur. Doktrin ve uygulamada, bu hükme göre tutulan ifade tutanaklarının birer belge delil aracı niteliğini mi taşıdığı, yoksa yalnızca yargıcın uyarı yükümlülüğğ çerçevesinde bir ihtarda bulunmasını mı düzenlediği, bir başka deyişle sorguyu değerlendirme aracı $\mathrm{ml}$ olduğu konusunda farklı görüssler mevcuttur ${ }^{82}$.

Bir görüşe göre, CMK. md. 213/1'de Cumhuriyet savcısı veya kolluk tarafından tutulan ifade tutanağı, kovuşturma evresinde geçerli olan doğrudan doğruyalık ilkesinin istisnasını oluşturan "belge delil aracı" niteliğindedir. Ancak, ifade tutanağının okunma yoluyla duruşmaya dahil edilmesi sonucunda içeriği ispatlanmış olmamakta, diğer delil araçları gibi serbest değerlendirmeye konu olmaktadır. Yargıç, okunan ifadeyi değerlendirerek hüküm verirken kullanabilir. Bu görüşü savunan yazar, CMK. md. 213/1'den bu hükme göre tutulan ifade tutanağının birer belge delili niteliğini haiz olduğunun kolaylıkla anlaşılabileceğini ileri sürmüştür ${ }^{83}$.

Diğer yandan bir başka görüş ise, tutulan ifade tutanağının tamamen uyarı amacıyla okunduğunu ileri sürmüş; hükme dayanak oluşturacak olanın, okunan ifade tutanağının değil, uyarı sonucunda sanığın duruşmada söylediklerinin olacağını savunmuştur ${ }^{84}$.

CMK. md. 213/1'de düzenlenen hükümdeki ifade tutanağının hukukî niteliğini belirlemek, varılacak sonuçlar açısından önem taşımaktadır. Bir belge delil aracı olduğu sonucunu benimsersek, okunan ifade tutanağının diğer delil araçlan gibi serbestçe değerlendirme kapsamına alınması gerekecektir. Diğer yandan, CMK. md. 213/1'deki ifade tutanağının bir uyarı amacıyla okunacağını kabul edersek, delil aracı olarak değerlendirilebilecek olan, okunan ifade tutanağı değil, uyarı üzerine sanığın yaptığı açıklamalar olacaktır ${ }^{85}$.

Kanaatimizce, CMK. md. 213/1 hükmü uyarınca, Cumhuriyet savcıs1 veya müdafi huzurunda kolluk tarafından tutulan ifade tutanağı, bir belge delil aracı niteliğindedir. Sanığın soruşturma evresinde Cumhuriyet savcısı

\footnotetext{
${ }_{83}^{82}$ Şahin, Ceza Muhakemesinde İspat..., s. 236.

${ }^{83}$ Tosun'a göre; delillerin vasıtasızlığı ilkesi gereği hakim, delillerle bizzat temas etmelidir. Yazar, hakimin, kolluk tutanağına dayanmasını kabul etmemektedir, ancak, bunun, söz konusu tutanaklara hiç değer verilmeyeceği anlamına gelmediğini ifade etmektedir. Şöyle ki, Tosun, tutanağı tutan kolluk memurlarının tanık olarak dinlenmesini mümkün kabul etmekte ve açıklamaların alelade delil olduğunu ileri sürmektedir. Bkz. Tosun, Öztekin, Türk Suç Muhakemesi Hukuku Dersleri, C. I, Genel Kısım, İstanbul 1984, s. 761.

${ }^{84}$ Yenisey, Feridun, Uygulanan ve Olması Gereken Ceza Muhakemesi Hukuku, Duruşma ve Kanunyolları, 2. Baskı, İstanbul 1990, s. 30.

${ }^{85}$ Şahin, Ceza Muhakemesinde İspat..., s. 241.
} 
veya müdafii huzurunda kolluk önünde yaptı̆̆ı açıklamalar, o evre için bir "delil aracı" niteliğindedir. Bunlar, kovuşturma evresinde diğer delil araçları gibi serbestçe değerlendirilecektir ${ }^{86}$.

Önceki ifadenin Cumhuriyet savcısı veya müdafi huzurunda kolluk tarafından düzenlenmiş olmasına rağmen, çelişki halinde sanığın ifadesinin duruşmada okunmaması, md. 213/1'in ve maddi gerçeğin araştırılmasının ihlalidir. Bundan başka, olayın aydınlatılması için daha birçok delil kaynağının araştırılması gerektiği halde, yalnızca CMK. md. 213/1'deki hükme dayanarak, önceki ifadenin okunması ile yetinilmesi de yine maddi gerçeğin araştırılması ilkesine aykırılık teşkil eder ${ }^{87}$.

\section{DEGERLENDİRME}

Muhakeme makamlarının algılamasının malzemesini oluşturan veya konusunu teşkil eden veya bu makamlara incelenecek malzeme ya da bilgi sunan dış dünyaya ait bir gerçeklik olan varlık "delil kaynağı" olarak adlandırılmaktadır. Delil kaynağı, henüz muhakeme makamları tarafından işlenmemiş bir malzeme veya muhakeme makamlarına ifade veren kişidir. Bir delil kaynağı, muhakeme makamlarının inceleme ve algılamasına sunulunca, bir delil aracı haline gelir. Bir delil kaynağı, delil aracı haline geldikten sonra, gerçeği temsil etmesi şartıyla kullanıldığ makamın şüphesini yenmesini gerekli olan ölçüde sağlıyorsa, o safha için "delil" niteliğini kazanacaktır. O halde, geçmişte olup bitmiş bir olayın muhakeme evrelerinde yeniden yaşanmasını sağlayan ispat gereçlerinin, delil niteliğini haiz olması yalnızca kovuşturma aşamasına özgü değildir. Soruşturma evresinde CMK. md. 170'de açıça belirtildiği üzere, Cumhuriyet savcısının toplanan delil araçlarını değerlendirdikten sonra,

${ }^{86}$ Gerek CD. gerekse YCGK. kararlarında, yargıç huzurunda alınan ikrarın diğer delil araçları gibi serbest değerlendirmeye konu olabileceği ve yan delil araçlarıyla da desteklenmesi gerektiği belirtilmiştir.

"Bir ikrarın sanık aleyhine delil olabilmesi için bunun serbest irade mahsülü olması, hakim huzurunda yapılması, soruşturma aşamaşnda geri alınmaması ve yan delillerle de doğrulanması gerekir...”. (YCGK., 16.2.1987-6-271/50). Yaşar, Osman, Açıklamalıİçtihatlı Ceza Muhakemeleri Usulü Kanunu, C. 1, Ankara 1998, s. 966; Savaş, Vural Mollamahmutoğlu, Sadık, Ceza Muhakemeleri Usulü Kanununun Yorumu, C. I, Ankara 1995, s. 1085.

'Kesinlik ve süreklilik kazanmış yargı düşüncesine ve CMUK.'nun 247. maddesi hükmüne göre, ikrarın kesin kanıt olarak kabul edilebilmesi için hakim huzurunda her türlü maddi ve manevi baskıdan uzak serbest irade ile yapılması, tutarlı yan delillerle doğrulanması ve işlenen fiilin oluşu ile uyumlu bulunması.....”. (8. C.D., 20.3.1985583/1390). Yaşar, s. 970.

“...CMUK.'nun 247. maddesine göre, ikrarın kesin kanıt olarak kabul edilebilmesi için, hakim huzurunda vuku bulması yanında, her türlü maddi ve manevi cebir, tehdit ve hileden uzak, serbest irade ile yapılması, fiilin işlenişiyle uyumlu yan delillerle de doğrulanması gerekmektedir". (8. C.D., 3.7.1986-2763/4070). Yaşar, s. 970.

${ }^{87}$ Şahin, Ceza Muhakemesinde İspat..., s. 227. 
iddianame hazırlayarak kamu davasının açılmasına karar vermesi, deliller konusunda yeterli şüphe elde etmiş olduğunun kabulünü gerektirir.

Gözaltında alınan ifade de, bir delil aracı olduğundan, soruşturma evresinde gerek diğer delil araçlarına ulaşmadaki, gerekse kamu davasının açılmasındaki önemi tartışılmazdır.

Hukuka uygun elde edilen ifade ile diğer delil araçlarına ulaşılması mümkündür. Önemli olan, ifadenin hukuka uygun yollarla elde edilmiş olmasıdır. Olaya ilişkin elde edilen yeni bilgiler, farklı ipuçları, soruşturmanın ilerlemesinde vazgeçilmez bir rol üstlenmektedirler. Hukuka aykırı olarak elde edilen diğer delil araçlarının muhakemede kullanılıp kullanılmayacağı sorunu doktrinde tartışmalı olmakla beraber, kanaatimizce "zehirli ağacın meyveleri de zehirlidir" ilkesi gereğince bu mümkün değildir. Hukuka aykırı yöntemlerin kanunda yasaklanması, insan haklarına karşı duyarlılığın bir göstergesidir. CMK. md. 217/2'de açıkça hukuka aykırı delil araçlarının dolaylı etkisini yasaklamamıştır. Yine de bu delil araçlarının muhakemede kullanılamayacağı ve hükme esas alınamayacağı sonucuna varmamız mümkündür. Zira hukuka aykırı delil araçlarının doğrudan etkisini yasaklama için bu hükmü yeterli görüp de, dolaylı etkisini bu kapsam dışında tutmak bir çeliş̧idir.

Alınan ifade sonucunda, isnadın konusunu oluşturan suç dışında, başka bir suç teşkil eden fiile ilişkin delil aracına ulaşmak mümkündür. Hukuka uygun alınan ifade sonucunda başka bir suça ilişkin delil araçları elbette ki, yeni suç için soruşturma evresine başlamakta bir başlangıç şüphesi olarak kullanılabilir. Bunun dışında hukuka aykırı elde edilen ifade vasıtasıyla başka delil araçlarına ulaşılması, söz konusu delil araçlarının bu suç hakkında soruşturma aşamasına başlangıç şüphesi teşkil edip etmeyeceği sorununu da beraberinde getirir. Biz, ulaşılan delil aracının Cumhuriyet savcısı veya kolluğun haberdar olduğu ve hakkında ceza muhakemesi yürütülen bir suç veya henüz Cumhuriyet savcısı veya kolluğun da bilgisinde olmayan yeni bir suç olmasına göre bir ayırım yapmaktayız. Savcının veya kolluğun haberdar olduğu başka bir suça ilişkin delil aracına ulaşılması durumunda bunu kullanmak mümkün değildir. Çünkü ifadeyi alan memur, hukuka aykırı yöntemi bu delil aracına ulaşmak için kullanabilir. Oysa ki, ifadeyi alan memurun henüz haberi bile olmadığı bir suçu ortaya çıkaran bu delil aracını, soruşturma evresi için başlangıç şüphesi olarak kullanması mümkündür. Çünkü, bu durumda memurun haberi bile olmadığından şüpheliye baskı yapması söz konusu olamaz.

Soruşturma evresinde alınan ifade, kamu davasının açılıp açılmamasında da önemini gösterir. Kanun koyucu, Cumhuriyet savcısına toplanan deliller konusunda yeterli şüphe elde ettiği takdirde iddianame hazırlamasını ve kamu davasını açma yükümlülüğünü getirmiştir. Cumhuriyet savcısı, en azından kendi içindeki şüpheyi yenmesini veya fiilin 
suç olduğuna dair çok az bir şüphe duymasını sağlayan delil araçlarını değerlendirip, kamu davasını açmak için iddianame hazırlayarak yeterli şüpheye ulaştığını gösterebilir. CMK. md. 170, Cumhuriyet savcısına delil araçlarını değerlendirme ve "delil" niteliğini haiz kılma yetkisi vermiştir.

İfade alma sırasında, ifade alan memurun hukuka aykırı davranışlarını iki başlık altında toplamak mümkündür. İfade alan memur, kişiye haklarını öğretmeden ifadesini alabilir. $\mathrm{Bu}$ durumda memur, aydınlatma yükümlülüğünü ihlal etmiş olur. CMK. md. 147'de yer alan aydınlatma yükümlülüğünün ihlal edilmesi halinde yaptırımının ne olacağı belirtilmemiştir. AY. md. 38'deki hükümle kanuna aykırı elde edilen delil araçları delil olarak değerlendirilemez. Aynı sonuca CMK. md. 217/2' den de ulaşmak mümkündür. CMK. md.217/2'nin yorumundan, hukuka aykırı elde edilen delil araçlarının ispat gücüne sahip olmadıkları anlaşılmaktadır. CMK. md. 217/2 bir kural hüküm olduğundan, klyasen soruşturma evresine de uygulamamız mümkündür. Bu durumda, hukuka aykırı olarak elde edilen delil araçları ve bir delil aracı olan ifade de, Cumhuriyet savcısının kamu davası açmak için yaptığı değerlendirmede delil değerini haiz olamayacaktır.

Soruşturma evresinde kamu davasının açılması için önemli olan ifade, kovuşturma evresinde de, CMK. md. 148/4 uyarınca, müdafi hazır bulunmaksızın kolluk tarafından düzenlenmesi ve sanığın sorgu sırasında bunu tekrarlaması şartıyla, bir delil aracı olarak değerlendirilebilir. Bu maddeye göre, müdafi bulunmaksızın kollukta alınan ifadeler, doğrudan kovuşturma evresinde bir delil aracı olarak okunamaz ve dolayısıyla hükme esas alınamaz.

Bunun yanında, CMK. md. 213'te ifadeler arasında çelişki olması halinde, savc1lık veya müdafi huzurunda kolluk tarafından tutulan ifade tutanağı duruşmada okunabilmektedir. Ancak sorun okumanın değerinin ne olacağıdır. Okumanın değeri, sanığa çelişkiyi giderme olanağı sağlamaktır. Okunan ifade tutanağı karşısında sanığın inkâr etme, kabul etme veya değiştirerek farklı bir beyanda bulunması söz konusu olur. Bu durumda, mahkeme gerekçesini göstererek, önceki ifadeye de değer atfedebilir. Bu şekilde, kovuşturma evresinde de Cumhuriyet savcısı tarafından veya müdafiin bulunması koşuluyla kolluk tarafından soruşturma sırasında alınan ifadeler hükme esas alınabilmektedir. 


\section{KAYNAKÇA}

Bıçak, Vahit, Avrupa Birliği İle İlişkilerin Hazırlık Soruşturmasına Etkisi, http://www.bilkent.edu.tr/\% 7Evahit/ar3.htm, Atıf Tarihi: 20.11.2007, s. 1-12.

Bıçak, Vahit, İnsan Hakları İhlallerinde Yönelimler: Baskıdan Hileye, http://www.bilkent.edu.tr/\%7Evahit/ar6.htm, Atıf Tarihi: 20.11.2007, s. 1-12.

Çağlayan, M. Muhtar, "Hazırlık Soruşturması Yapılırken Gözönünde Tutulması Gereken Önemli Noktalar Üzerinde Bir İnceleme", AD 1979, S. 3-4, s. 162-175.

Centel, Nur - Zafer, Hamide, Ceza Muhakemesi Hukuku, 5. Bası, İstanbul 2008.

Cihan, Erol - Yenisey, Feridun, Ceza Muhakemesi Hukuku, 3. Tipk1 Basım, İstanbul 1998.

Demirbaş, Timur, "Hazırlık Soruşturmasında Müdafiilik", CMUK Sempozyumu İnsan Hakları Avrupa Sözleşmesi ve Avrupa İnsan Hakları Mahkemesi Kararları Karşısında 70. Yıldönümünde Ceza Muhakemeleri Usulü Kanunu (9 Nisan 1999 - İstanbul), İstanbul 1999, s. 91-118.

Demirbaş, Timur, "Soruşturma Evresinde Şüphelinin İfadesinin Alınması ve Müdafilik", LHD, Y. 3, S. 32, Ağustos 2005, s. 2871-2883.

Demirbaş, Timur, Sanı̆̆ın Hazırlık Soruşturmasında İfadesinin Alınması, İzmir 1996.

Demirbaş, Timur, Türk Ceza Hukukunda İşkence Suçu, Ankara 1992.

Eryılmaz, M. Bedri, "Kolluğun Yetkileri Açısından Ceza Muhakemeleri Usulü Kanunu (CMUK) ile Yeni CMUK Tasarısının Düşündürdükleri”, ABD 2000, C. 57, S. 1, s. 47-96.

Feyzioğlu, Metin, Ceza Muhakemesi Hukukunda Tanıklık, Ankara 1996.

Feyzioğlu, Metin, Ceza Muhakemesinde Vicdani Kanaat, Ankara 2002.

Hafızoğulları, Zeki, "Hukuka Aykırı Elde Edilen Deliller Meselesi”, Yeni Türkiye, Temmuz - Ağustos 1996, Y. 2, S. 10, s. 638-643.

Hall, Daniel E., Criminal Procedure and The Constitution, USA 1997.

İçel, Kayıhan, "Sorgulamada Hukuka Aykırılık ve Sonuçları", Savaş, Vural - Mollamahmutoğlu, Sadık, Ceza Muhakemeleri Usulü Kanununun Yorumu, C. I, Madde 1-257, Ankara 1995, s. 734-742.

Kantar, Baha, Ceza Muhakemeleri Usulü, Ankara 1957. 
Kaymaz, Seydi, “Aydınlatma Yükümlülüğünün İhlali Sebebiyle Sözkonusu Olan Yasak Deliller", YD, Temmuz 1997, C. 23, S. 3, s. 280-300.

Kaymaz, Seydi, Uygulamada ve Teoride Ceza Muhakemesinde Hukuka Aykırı (Yasak) Deliller, Ankara 1997.

Keskin, Serap, Ceza Muhakemesi Hukukunda Temyiz Nedeni Olarak Hukuka Aykırılık, İstanbul 1997.

Koca, Mahmut, "Ceza Muhakemesi Hukukunda Deliller", CHD, Y. 1, S. 2 , Aralık 2006, s. 207- 225.

Koca, Mahmut, "Ceza Muhakemesinde Hukuka Aykırı Delilleri Değerlendirme Yasağı”, EÜHFD 2000, C. IV, S. 1-2, s. 105-146.

Kunter, Nurullah - Yenisey, Feridun - Nuhoğlu, Ayşe, Muhakeme Hukuku Dalı Olarak Ceza Muhakemesi, 14. Bası, İstanbul 2006.

Kunter, Nurullah - Yenisey, Feridun, Muhakeme Hukuku Dalı Olarak Ceza Muhakemesi Hukuku, 11. Bası, İstanbul 2000.

Kunter, Nurullah, Muhakeme Hukuku Dalı Olarak Ceza Muhakemesi Hukuku, 9. Bası, İstanbul 1989.

Odman, M. Tevfik, “Askeri Yargitay'ın Hukuka Aykırı Deliller Konusunda Verdiği Kararlar”, AAD, Ocak 1996, Y. 24, S. 95, s. 9-34.

Odman, M. Tevfik, "Hukuka Aykırı Şekilde Elde Edilen Delillerin Kullanılma Sorunu”, İnsan Hakları Merkezi Dergisi, Kasım 1995, C. 3, S. 4, Ankara 1996, s. 20-30.

Özgen, Eralp, "İşkence ve İnsanlık Dışı Davranışlara Karşı Birleşmiş Milletler Andlaşması", TBBD, Eylül 1988, S. 2, s. 208-233.

Özgen, Eralp, Ceza ve Ceza Muhakemesi Hukuku Bilgisi, Eskişehir 1988.

Öztürk, Bahri - Erdem, Mustafa R., Uygulamalı Ceza Muhakemesi Hukuku, 11. Baskı, Ankara 2007.

Öztürk, Bahri, "CMUK Reformu ve Delil Yasakları”, SÜHFD 1994, C. 4, S. 1-2, s. 39-50.

Öztürk, Bahri, "CMUK Reformu ve Uygulama”, Yeni Türkiye, Temmuz Ağustos 1996, Y. 2, S. 10, s. 586-612.

Öztürk, Bahri, Ceza Muhakemesi Hukukunda Koğuşturma Mecburiyeti (Hazırlık Soruşturması), Ankara 1991.

Öztürk, Bahri, Uygulamalı Ceza Muhakemesi Hukuku, 3. Baskı, Ankara 1995.

Öztürk, Bahri, Yeni Yargıtay Kararları Işı̆̆ında Delil Yasakları, AÜSBF Yayınlan, Ankara 1995. 
Şahin, Cumhur, "Yargıtay Kararları Işığında Hukuka Aykırı Deliller ve Değerlendirilmesi Sorunu", EÜHFD 1997, C. 1, S. 1, s. 87-95.

Şahin, Cumhur, Ceza Muhakemesinde İspat (Delillerin Doğrudan Doğruyalığg İlkesi), Ankara 2001.

Şahin, Cumhur, Sanığın Kolluk Tarafından Sorgulanması, Ankara 1994.

Savaş, Vural - Mollamahmutoğlu, Sadık, Ceza Muhakemeleri Usulü Kanununun Yorumu, C. I, Ankara 1995.

Toroslu, Nevzat - Feyzioğlu, Metin, Ceza Muhakemesi Hukuku, Ankara 2006.

Toroslu, Nevzat, "Hukuka Aykırı Deliller Sorunu", Prof. Dr. Hamide Topçuoğlu'na Armağan, Ankara 1995, s. 55-58.

Tosun, Öztekin, Ceza ve Medeni Muhakeme Hukuku Açısından Hukuka Aykırı Yollarla Elde Edilmiş Delillerin İspat Kuvveti, İstanbul 1976.

Tosun, Öztekin, Türk Suç Muhakemesi Hukuku Dersleri, C. I, Genel Kisım, İstanbul 1984.

Ünver, Yener, "Ceza Muhakemesinde İspat, CMK ve Uygulamamız", CHD, Y. 1, S. 2, Aralık 2006, s. 103-205.

Ünver, Yener, "Deliller ve Değerlendirilmesi”, LHD, Y. 3, S. 32, Ağustos 2005, s. 2885-2913.

Yaşar, Osman, Açıklamalı-İçtihatlı Ceza Muhakemeleri Usulü Kanunu, C. 1, Ankara 1998.

Yenisey, Feridun, "Yasak Yöntemlerle ve Hukuka Aykırı Şekilde Elde Edilen Deliller", 24.10.1994 Yargıtay'da sunulan tebliğ, Savaş, Vural - Mollamahmutoğlu, Sadık, Ceza Muhakemesi Usulü Kanununun Yorumu, C. I, Madde 1-257, Ankara 1995, s. 12141239.

Yenisey, Feridun, İnsan Hakları Açısından Arama, Elkoyma, Yakalama ve İfade Alma ve İlgili TCK - CMUK Maddeleri, AÜSBF Merkezi Yayınları, Ankara 1995.

Yenisey, Feridun, Uygulanan ve Olması Gereken Ceza Muhakemesi Hukuku, Duruşma ve Kanunyolları, 2. Baskı, İstanbul 1990. 